\title{
The Demarcation of Straddling Villages in Accordance with the International Court of Justice Jurisprudence: The Cameroon-Nigeria Experience
}

\author{
Gbenga Oduntan*
}

Bi a ba ran eniyan ni ise eru ologbon afi ti omo je (Where instructions are insensitive and befitting of a slave, a reasonable fellow amends it sensitively and delivers it in a manner befitting the free). ${ }^{1}$

\begin{abstract}
The existence of straddling settlements between Cameroon and Nigeria is one of the features of their geographical location as neighbouring West African States. Although the existence of these settlements did not constitute a central part of the boundary dispute between both States, implementation of the recent World Court judgment presents crucial dilemmas as to the treatment of straddling communities in particular and, to some extent, boundary villages as well. This article explores the alternatives that may be adopted in attaining a fair and just implementation of the Court's judgment in relation to straddling villages and boundary communities. The delimitation and demarcation of straddling villages and villages that fall into another State's territory are bound to be an increasingly common feature of
\end{abstract}

* PhD (Law (Kent)), MA, LLB (hons), BL (hons), BA (hons); Lecturer in Law, Kent Law School, University of Kent, Canterbury, UK (email: O.T.Oduntan@kent.ac.uk; web address: www.kent.ac.uk/law/people/ index.htm); Member, United Nations-Nigeria/Cameroon Mixed Sub-Commission on the Demarcation of the Boundary between Nigeria and Cameroon. The positions and opinions expressed in this paper are those of the author in their entirety and do not reflect in any way whatsoever the official position of the Nigerian government or any part of the United Nations-Nigerian/Cameroon Mixed Commission or its Sub-Commission.

1 Yoruba Legal Maxim. 
the work of international courts and demarcation commissions as populations increase and the need to definitively specify borders increases. It is, therefore, necessary that a specialized jurisprudence is developed for this area of law. This article, therefore, attempts to highlight difficulties in the jurisprudence of the International Court of Justice in its work in this area and suggests a typology of factors that may be adopted in varying delimitation lines by adjudicators and demarcators. It also attempts a digest of what may represent good practice in the law of boundary delimitation and demarcation by examining similar cases around the world. The argument presented is that there is enough within the corpus of international law and international relations for courts to avoid splitting communities needlessly or subjecting populations to the whims and caprice of hostile States' territorial jurisdiction, particularly in relation to a continent such as Africa, which has suffered a long and unfair history of balkanization of its peoples and civilizations. The article makes the case that the World Court needs more law elaboration if not judicial activism in its delimitation work to avoid inadvertent complicity in the abuse of peoples' rights and to attain a more robust resolution of boundary disputes. The view advanced is that where aspects of the Court's delimitation may be unsatisfactory and contrary to the mutual interests of disputants, those charged with the task of implementing the Court's judgment must not be slavish in their appreciation of the spirit of judicial resolution. Where there is the danger that human and generational rights would be needlessly compromised, nothing apart from an unimaginative and unco-operative approach prevents demarcators from independently adopting a more holistic resolution of the dispute in the interest of human justice, such as by (within very strict limits) varying delimitation lines suggested by the Court in particular sectors.

\section{Introduction}

Cameroon and Nigeria are States situated on the west coast of Africa. Their land boundary extends from Lake Chad in the north to the Bakassi Peninsula in the south. Their coastlines are adjacent and are washed by the waters of the Gulf of Guinea. Four States border Lake Chad: Cameroon, Chad, Niger and Nigeria. The waters of the Lake have varied over time and it is common knowledge that various native groups tend to follow the receding waters and cultivate the arable land it leaves behind. In its northern part, the land boundary between Cameroon and Nigeria passes through hot, dry plains around Lake Chad, at an altitude of about 300 metres. It passes through mountains, cultivated high grounds or pastures, watered by various rivers and streams. It then descends in stages to areas of savannah and forest, until it reaches the sea in Southern Nigeria.

Relations between Cameroon and Nigeria have long been strained due to problems along their common border, which is more than 1700 kilometres long and extends from Lake Chad to the sea. These problems were aggravated by the mutual challenge of sovereignty over the Bakassi Peninsula and Lake Chad. Tensions between the two countries degenerated into military confrontation at the end of 1993. In 1994, Cameroon brought the case of the border dispute between the two countries to the International Court of Justice (ICJ). On 10 October 2002, the ICJ issued its judgment deciding the issues brought before it and, 
inter alia, delimited the boundaries of both countries throughout their entire mutual land boundary. ${ }^{2}$

The Land and Maritime Boundary case remains one of the most controversial decisions reached by the Court in recent times. Both sides are deeply dissatisfied with aspects of the judgment. Certainly, within Nigeria, the Court's judgment has been greeted with unprecedented national uproar and angry reactions, primarily because of the rejection of the ownership claims over Bakassi. Several vocal sections of the Nigerian population, including legal jurists, politicians and government officials, have been arguing for outright rejection of the judgment of the Court, and quite ominously have been publicly proffering military solutions to the dispute. Although the Nigerian government has stated that it accepts the Court's judgment, it has on the other hand continued to maintain clearly that the Court's verdict "is difficult to implement". ${ }^{3}$ However, with the assistance of the United Nations, Cameroon and Nigeria have looked for the most efficient ways and means of ensuring the peaceful implementation of the ICJ judgment. This approach led to the establishment of the Cameroon-Nigeria Mixed Commission-an ongoing body that has performed remarkably successfully given the difficult nature of the tasks before it. ${ }^{4}$ To assist this body in its important tasks, two Sub-Commissions were created to assist the Mixed Commission with its ground-breaking work. The first is the Trilateral SubCommission on Demarcation (involving boundary commissioners and legal experts from the United Nations, Cameroon and Nigeria) - a body which uniquely continues to perform its functions despite intermittent lulls in the work of its parent Commission. ${ }^{5}$ The second is the Sub-Commission on the rights of the affected populations-a body

2 See Land and Maritime Boundary between Cameroon and Nigeria (Cameroon v. Nigeria: Equatorial Guinea Intervening), Judgment, Preliminary Objections [1998] IC] 2, 11 June 1998 (www.worllii.org/int/cases/ ICJ/1998/2.html); Request for Interpretation of the Judgment of 11 June 1998 in the Case Concerning the Land and Maritime Boundary between Cameroon and Nigeria (Cameroon v. Nigeria), Preliminary Objections (Nigeria v. Cameroon) (www.icj-cij.org/icjwww/idocket/icn/icnjudgment/icn_ijudgment_19990325_frame. htm); Land and Maritime Boundary between Cameroon and Nigeria (Cameroon v. Nigeria: Equatorial Guinea Intervening), Judgment, Merits, 10 October 2002 (www.icj-cij.org/icjwww/idocket/icnjudgment/); see particularly para. 30 .

3 See BBC News, 23 October 2002, Nigeria Rejects World Court Ruling (http://news.bbc.co.uk/2/hi/africa/ 2353989.stm); Sara McLaughlin Mitchell and Paul R. Hensel, International Institutions and Compliance with Agreements (http://garnet.acns.fsu.edu/ phensel/Research/ajps05.pdf); BBC News, 15 September 2004a, Nigeria Downplays Bakassi Delay (http://news.bbc.co.uk/go/pr/fr/-/2/hi/africa/3652150.stm); BBC News, 12 November 2002, Nigeria Rules Out Bakassi War (http://news.bbc.co.uk/2/hi/africa/ 2447407.stm).

4 The Mixed Commission was established in accordance with the decision arrived at by the Heads of State of Nigeria and Cameroon in the presence of the UN Secretary-General during their Summit in Geneva Switzerland on 15 November 2002. The task of this Mixed Commission is to ensure the implementation of the Courts Judgment of 10 October 2002. See further Nigeria First Official Website of the office of Public Communications, UN Mixed Commission (www.nigeriafirst.org/article_252.shtml). Materials relating to the activities of the Trilateral Mixed Commission are available at the official website of the United Nations Office for West Africa UNOWA (http://www.un.org/Depts/dpa/prev_dip/africa/office_for_srsg/ fst_office_for_srsg.htm).

5 See para. 8 of the Communiqué Adopted at the First Meeting of the Cameroon-Nigeria Mixed Commission Established Pursuant to the Joint Geneva Communiqué of 15 November 2002 (Yaoundé, 1-2 December 2002); above n.4. 
which has completed its tasks and submitted a comprehensive report to the Mixed Commission. ${ }^{6}$

Although there are many points under which the Court's decisions in the Land and Maritime case may be of interest to international lawyers and experts of international relations, the purpose of this paper is to examine the modalities for resolving the issue of demarcation of straddling villages that exist between both countries. ${ }^{7}$ Possible alternatives to resolve the impasse that may be expected in this area are suggested and it is argued that the parties to the ongoing negotiations ought to think innovatively about the problem. The argument is advanced that the most desirable option is, as a matter of principle, to always leave the entire communities within a single State. Where this is not possible at all, other well thought-out and negotiated solutions that are not limited by strict resort to bare provisions of a legal delimitation ought to be explored.

\section{The ongoing process of demarcation of the land boundary}

It is notable that although immense progress has been made in the implementation of the Court's judgment in the last few months, the process of actual demarcation of the land boundary is just taking off. Progress made in other areas includes the mutual withdrawal of civil administration, military and police forces and transfer of authority in the Lake Chad area, which was completed on 18 December 2003. The process took place in phases, with some 33 villages surrounding Naga'a, Tchika, Doron Liman and Darack handed over to Cameroon, and Damboré to Nigeria. A Working Group on the withdrawal

6 In accordance with paras 6 and 7 of the Yaoundé Communiqué of 2 December 2002, the Mixed Commission decided to establish a Sub-Commission on Affected Populations with a mandate to consider modalities relating to the protection of their rights. See also para.7 of the Communique Adopted at the Second Meeting of the Cameroon-Nigeria Mixed Commission Established Pursuant to the Joint Geneva Communiqué of 15 November 2002 (Abuja, 4-5 February 2003) and para.4 of the Communiqué Adopted at the Third Meeting of the Cameroon-Nigeria Mixed Commission Established Pursuant to the Joint Geneva Communiqué of 15 November 2002 (Yaoundé, 2-3 April 2003). The Sub-Commission included demographers, human-rights experts, cartographers, sociologists and lawyers from the two parties and the United Nations. As agreed at the eighth meeting of the Mixed Commission, which took place in Abuja from 10 to 11 February 2004, the two Sub-Commissions undertook a field visit to the land boundary and to the Bakassi peninsula, respectively, from 15 February to 1 March 2004. At its ninth meeting in Yaoundé in April 2004, the Mixed Commission decided to refer the report to the bilateral Cameroon-Nigeria Joint Commission-a body of long-standing existence and which is not involved in the implementation of the ICJ Judgment. See further Lukong Pius Nyuylime, Cameroon: Effective Nigerian Withdrawal Begins in July, Cameroon Tribune, 4 December 2004, Africa News Update, the Norwegian Council for Africa (www.afrika.no/Detailed/5155.html).

7 Other issues of academic interest that are beyond the scope of the present enquiry include: the modalities for development of a progressive regime for the fishing rights of native populations affected by the Court's judgment; resolution of the continuing dispute over parts of the territory and population in the Bakassi Peninsula which represents the fons origo of the entire dispute between the two States; the technical issues concerning the scientific demarcation of the boundary between both countries; protection of the rights of the affected populations in the Lake Chad area and other populations along the boundary affected by the ICJ decision as well as the bilateral and multilateral diplomacy that has attended the 10 October 2002 judgment of the ICJ. For a criticism of the Court's judgment in this case, as well as wider enquiries into the theme that Eurocentric international courts and tribunals are ill-suited for the task of resolution of African boundary and territorial dispute, see Gbenga Oduntan, Africa Before the International Courts: The Generarional Gap in International Adjudication and Arbitration, 5 The Journal of World Investment and Trade, No.6 (December 2004), 975. 
of civil administration and military and police forces and the transfer of authority in the Lake Chad area completed its work in January $2004 .^{8}$ Another Working Group on Withdrawals and Transfers of Authority in both the Land Boundary and the Bakassi Peninsula continues its work presently.'

Perhaps the main task before the parties is to achieve a demarcation of their 1700-kilometre land boundary in accordance with the decision of the ICJ. Thus, one of the first acts of the Mixed Commission was to establish the Sub-Commission on Demarcation, which has been charged with the responsibility of demarcation of the land boundary between the two States. The Sub-Commission is composed of legal experts and cartographers from the two parties and the United Nations. It met in January 2003 to prepare a small-scale map indicating the boundary and to consider the nature and characteristics of maps needed for the demarcation. On the basis of these, the Mixed Commission has decided on a work plan for the Sub-Commission. It has since been meeting regularly and its work has progressed rapidly. ${ }^{10}$

At its first meeting, held in Geneva, January 2003, the Sub-Commission on Demarcation established a trilateral Joint Technical Team (JTT) which also meets on a regular basis and handles the field operations of the Sub-Commission on Demarcation. On 9 February 2005, the JTT decided to undertake a pilot field assessment from 7 March to 6 April 2005. This activity heralds the beginning of the actual demarcation of the boundary-a process which would include Geodetic Ground Survey control, Geodetic Datum Stations Emplacement, Boundary Pillar Emplacement, as-built Pillar Survey and production of documents and final maps. The JTT adopted technical guidelines to be used by the JTT during the pilot field assessment. The work of the pilot field assessment has since commenced and the entire demarcation of the land boundary is scheduled for conclusion by the third quarter of 2006 .

\section{The problem of straddling villages}

The work of the JTT has reached a crucial stage at which it is expected to begin a strict implementation of the judgment with reference to the delimitation by the ICJ, the applicable

8 The Working Group's mandate was to implement the decisions of the Mixed Commission pertaining to the withdrawal from the Lake Chad in accordance with a strict working calendar. The Working Group's activities included all practical matters relating to the withdrawal of civil administration and military and police forces and the transfer of authority in the Lake Chad area, including the deployment of Mixed-Commission observer personnel. Communiqué Adopted at the First Special Meeting of the Cameroon-Nigeria Mixed Commission (Abuja, 28 October 2003).

9 See UNOWA, Cameroon-Nigeria Mixed Commission: Background (www.un.org/Depts/dpa/prev_dip/ africa/office_for_srsg/cnmc/bkground.htm); for a brief statement of the diplomatic efforts aimed at implementing the judgment, as well as estimated costs, see the Cameroon-Nigeria Mixed Commission, Sub-Commission on Demarcation of the Land Boundary, Application for Funds to the Donor Community, July 2003, 1. The Mixed Commission approved the document entitled "Application for Funds to the Donor Community" which was circulated among friendly States as a background document to help mobilize funds for demarcation activities. See Communiqué Adopted at the Fifth Meering of the Cameroon-Nigeria Mixed Commission Established Pursuant to the Joint Geneva Communiqué of 15 November 2002 (Yaoundé, 5-6 August 2003), para.9.

10 See Communiqué Adopted at the First Meeting of the Cameroon-Nigeria Mixed Commission Established Pursuant to the Joint Geneva Communiqué of 15 November 2002. See also para. 11 of the report adopted at the fifth meeting of the Sub-commission on Demarcation. See above n.4. 
colonial treaties and the technical guidelines under which it operates. ${ }^{11}$ Both the JTT and its parent body, the Sub-Commission on Demarcation, are bound by the decision of the Mixed Commission to implement the decision of the ICJ seemingly without any discretion to vary the delimitation in the light of geographical realities, local circumstances or considerations of justice.

Interestingly, this position is at variance with the treatment of straddling villages by the Court to the extent that it has deliberately left the resolution of this issue for the parties to achieve at a later time. It is fair to mention that the ICJ was not aware of the total number of straddling villages that feature along the boundary between both States. Indeed, the parties themselves are still going through the painstaking process of traversing the entire boundary in the process of which more such straddling communities are likely to be discovered. However, in those places where the Court itself noted the problem of straddling communities, it is arguable that its jurisprudence has not been very helpful in reducing the risk of grave injustice against the lives and economic livelihood of the concerned people as a result of the demarcation process.

Straddling villages include Cameroonian (Turu, Mogode, Furu Awa) and Nigerian (Bourha Wango, Kotcha, Dumo, Dorofi) ones. Apart from the straddling villages and communities, there are also settlements that deserve special attention in the demarcation processes because of their closeness to the delimited boundary. These include Banki and Amchide, which are separated by a narrow corridor through which the boundary runs. The implementation process has witnessed the exercise of stark choices by citizens of both countries. Some Nigerians that were cut off by the delimitation of Narki into Cameroon chose to relocate into Nigeria with the help of the Nigerian government. This is despite the clear communication to such populations that there is no obligation to relocate. It is, however, clear that the rights of the affected population that may be affected by delimitation and demarcation in these areas include the rights to citizenship, property, security and non-discrimination, as well as customary rights and practices.

It is worthy of note that there are numerous international instruments to which both Cameroon and Nigeria are parties and which are definitive of their obligations towards the affected population and have been informing their common approach to the overall implementation task. These are: the Universal Declaration of Human Rights (1948); the African Charter on Human and People's Rights (1981); the International Covenant on Civil and Political Rights (1966); the Optional Protocol to the International Covenant

11 The Court noted in para.82 that both States agree that the land boundary between their respective territories from Lake Chad onwards has already been delimited, partly by the Thomson-Marchand Declaration incorporated in the Henderson-Fleuriau Exchange of Notes of 1931, partly by the British Order in Council of 2 August 1946 and partly by the Anglo-German Agreements of 11 March and 12 April 1913. The Court likewise notes that, with the exception of the provisions concerning Bakassi contained in Arts XVIII et seq. of the Anglo-German Agreement of 11 March 1913, Cameroon and Nigeria both accept the validity of the four above-mentioned legal instruments which effected this delimitation. On the whole, the Court's delimitation involved some 17 points that were in dispute along the entire land boundary. See ICJ Reports 2002, 360, para.86. The interpretation and application of the Thomson-Marchand Declaration of 1929-30 constituted the major part of the Court's work. 
on Civil and Political Rights (1966); the International Covenant on Economic, Social and Cultural Rights (1966); the International Convention on the Elimination of all Forms of Discrimination against Women (1979); the Convention against Torture and other Cruel, Inhuman or Degrading Treatment or Punishment (1984); the Convention on the Rights of the Child (1989); the Geneva Conventions on Humanitarian law; the Memorandum of Understanding governing the control of movements of persons and goods between the Federal Republic of Cameroon and the Federation of Nigeria. ${ }^{12}$ In addition to these, there is a broad range of international instruments to which both countries are parties exclusively of the participation of the other. These instruments can also be relied upon in the protection of the individuals and group rights of the affected population. $^{13}$

It may also be noted that the constitutions of both States contain specific provisions guaranteeing the protection of human rights and freedoms. In addition to this, both Nigeria ${ }^{14}$

12 Signed in Yaoundé on 6 February 1963.

13 Nigeria is also party to the following treaties to which Cameroon is not party: the Second Optional Protocol to the International Covenant on Civil and Political Rights, aimed at the abolition of the death penalty (1989); the Optional Protocol to the Covenant on the Elimination of All Forms of Discrimination Against Women (2000); the Optional Protocol to the Convention on the Rights of the Child on the Involvement of Children in Armed Conflict (2000); the Optional Protocol to the Convention on the Rights of the Child on the Sale of Children, Child Prostitution and Child Pornography (2000); the International Convention on the Protection of the Rights of all Migrant Workers and Members of the their Families (1990). Cameroon is party to the following treaties to which Nigeria is not party: Convention of 21 March 1950 for the Suppression of the Traffic in Persons and of the Exploitation of the Prostitution of Others (accession:

19 February 1982); International Convention of 11 October 1933 for the Suppression of Traffic in Older Women (succession: 27 October 1961); Supplementary Convention of 7 September 1956 on the Abolition of Slavery, the Slave Trade and Institutions and Practices Similar to Slavery; Protocol of 1953 amending the Slavery Convention of 1926; International Labour Organisation (ILO) Convention No.29 Concerning Forced Labour, 1930 (signed 13 September 1962); ILO Convention No.87 Concerning Freedom of Association and Protection of the Right to Organize, 1948 (ratified 7 June 1960); ILO Convention No.98 Concerning the Right to Organise and to Bargain Collectively, 1949 (signed 3 September 1962); ILO Convention No. 100 Concerning the Right to Organise and to Bargain Collectively, 1949 (signed 3 September 1962); ILO Convention No.100 Concerning Equal Remuneration for Men and Women Workers for Work of Equal Value, 1951 (signed 15 May 1970); ILO Convention No.111 Concerning Discrimination in Respect of Employment and Occupation, 1958 (signed 15 May 1988); Convention of 28 July 1951 Relating to the Status of Refugees (acceded through succession on 23 October 1961); Protocol of 31 January 1967 Relating to the Status of Refugees (accession: 19 September 1967); Convention of 26 November 1968 on Non-Applicability of Statutory Limitation to War Crimes and Crimes against Humanity (accession: 6 October 1972); International Convention of 30 November 1973 on the Suppression and Punishment of the Crimes of Apartheid (accession: 1 November 1976); Organisation of African Unity Convention of 7 September 1969 Governing the Specific Aspects of Refugee Problems in Africa; African Charter on the Rights and Welfare of the Child, 1993 (ratified on 5 September 1997).

14 Land Use Act, Cap.202, Vol.XI; Legal Aid Act, Cap.205, Vol.XI (Legal Aid Council); Immigration Act, Cap.171, Vol.X; Penal Code, Cap.345, Vol.XIX; Criminal Code Act, Cap.77, Vol.V; Criminal Code Act, Cap.80, Vol.V; Criminal Procedure Act, Cap.80, Vol.V; Women and Children's Rights Act, 2003; Constitution of the Federal Republic of Nigeria, 1999, Chapter II Fundamental Objectives and Directives and Directive Principles of State Policy; Chapter IV Citizenship; Fundamental Rights; Fundamental Rights (Enforcement Procedure) Rules; Fifth Schedule, Pt I: Code of Conduct for Public Officers, s.9: Abuse of Powers; Code of Conduct for Public Officers, s.9: Abuse of Powers; Code of Conduct for Public Officers, s.9: Abuse of Powers; Code of Conduct Bureau, s.15; Code of Conduct Tribunal, s.17. 
and Cameroon ${ }^{15}$ have within their domestic spheres an extensive body of legislation that is directly related or relevant to the protection of human rights. Bearing in mind the extensive nature of the rights to be preserved, it is clear that strict demarcation without more may gravely endanger long-established rights in national and international laws.

The concept of straddling villages is largely undefined in law. Although reference has been made to the terms "straddling village", "straddling community" or "straddling city" in legal and political literature, there has been no authoritative definition of the term. International case law on boundary and territorial disputes also does not offer a ready source of a definition because although international courts have referred to straddling villages in their judgments and indeed pronounced on their fate, they have dealt with the phenomenon simply as a finding of fact, with the aim of awarding them to one State or another and not as a conceptual category in law. It is arguably for this reason that the jurisprudence of courts and demarcators in dealing with the phenomenon of straddling villages/communities tends to be unsatisfactory.

It may be suggested that a straddling village/community/city is an organic human settlement, the physical appurtenances (houses, dwellings, farms, cultivated fields, designated grazing areas, etc.) of which overlap the territory of two or more sovereign States. In other words, the terms cover any settlement part of which has crossed over the legal, factual or notional boundary between at least two States.

The problem of straddling villages was presented by the ICJ in paragraph 107 of the judgment, as follows:

As regards the village of Turu, the Court recalls moreover that, while it may interpret the provisions of delimitation instruments where their language requires this, it may not modify the course of the boundary as established by those instruments. In the present case, the Parties do not dispute that the boundary follows the line of the watershed. That boundary line may not therefore be modified by the Court. Hence, if it should prove that the village of Turu has spread into Nigerian territory beyond the watershed line, it would be up to the Parties to find a solution to any resultant

15 Act No.97/012 of 10 January on the Conditions for Entry into, Residence in and Departure from Cameroonian Territory, and Decree No.2000/286 of 12 October specifying the Conditions for the Entry, Residence and Departure of Foreign nationals; Act No.90/ 052 of 19 December 1990 on Freedom of Social Interaction; Act No.90/053 of 19 December 1990 on Freedom of Association; Act No.90/054 of 19 December 1990 on the Maintenance of Public Order; Act No.90/055 of 19 December 1990 on Governing Public Events and Meetings; Act No.90/058 of 19 December 1990 modifying Act No.89/019 of 29 December 1989 on the Organisation of the Judicial System; Act No.90/060 of 19 December 1990 on the Establishment and Organisation of the Court of National Security; Act No.90/060 of 19 December 1990 on the Establishment and Organisation of the Court of National Security; Act No.90/061 of 19 December 1990 modifying certain provisions of the Penal Code; Act No.97/009 modifying and supplementing certain provisions of the Penal Code and penalizing torture; Act No.90/031 of 10 August 1990 on Commercial Activities in Cameroon; Act No.90/063 of 19 December 1990 modifying and supplementing certain provisions of Acts No.69/LF 18 of 10 November 1969 and No.84/001 of 4 July 1984 establishing a system covering insurance, old-age pensions, disability and death; Order-in-council No.90/1459 of 8 November 1990 establishing the Commission Nationale des Droits de L'Homme et des Liberties (CNDL)/National Human Rights and Freedoms Commissions; Order in Council No.91/287 of 21 June 1991 establishing the Conseil National de la Communication (CNC)/National Communication Council. 
problems, with a view to ensuring that the rights and interests of the local population are respected. [Emphasis added.]

Similarly, in paragraph 123 , the Court finds that:

... in the Kotcha area, the difficulty derives solely from the fact, as Nigeria recognizes, that the Nigerian village of Kotcha has spread over onto the Cameroonian side of the boundary. As the Court has already had occasion to point out in regard to the village of Turu, it has no power to modify a delimited boundary line, even in a case where a village previously situated on one side of the boundary has spread beyond it. It is instead up to the Parties to find a solution to any resultant problems, with a view to respecting the rights and interests of the local population'. [Emphasis added.]

It is a fact that both States have villages that have spread across the newly delimited boundary lines. In addition to Turu, which has encroached several hundred metres into Nigerian territory, there are other Cameroonian villages, such as Mabas and Mogode, that clearly straddle the international boundary. It may even be expected that more of such straddling villages may be revealed as satellite imagery over the 1200-kilometre boundary between both States is acquired and receives closer attention. Thus, the negotiation route opened by the Court is commendable and is of mutual benefit to the parties. The opportunity ought to be seized by the parties. This is more so because the Court's practice in delimitation of boundaries has traditionally been lacking in a proper consideration of the effects of its judgments on the lives and circumstances of people. This has been very much criticized on the basis that it does not accord with the demands of natural justice and only leads to the creation of future conflicts and severe hardship on native populations. Indeed, when Nigeria argued for a small deviation of the boundary off the watershed in the area of Koja, which is located in Adamawa State, south of Mubi, in order to encompass the traditional farmlands of the local inhabitants and Cameroon argued that a watershed should remain the boundary, despite the delimitation instrument referring to a possible deviation at this point, the Court supported Cameroon's view, stating in paragraph 124 as follows: ${ }^{16}$

... the boundary in the Kotcha area, as described in paragraphs 26 and 27 of the Thomson-Marchand Declaration, follows the line of the watershed, including where it passes close to the village of Kotcha, the cultivated land lying on the Cameroonian side of the watershed remaining on Cameroonian territory.

The Court on previous occasions has also stated that in its task of delimitation, it will not consider as of direct legal significance a claim that is "based on historic titles (or) is also based on reason of crucial human necessity". ${ }^{17}$ Inequality of natural resources or consequential injustices as would occur where a family is separated from its farms have also been summarily dismissed as irrelevant for the determination of a land frontier which came into

16 See paras $121-4$.

17 See Land, Island and Maritime Frontier Dispute (El Salvador/Honduras: Nicaragua Intervening) ICJ Reports, 1992,396 , para. 58 . 
existence after independence. ${ }^{18}$ This problem is compounded by the fact that in recent practice, the demarcation of boundaries in Africa has been unduly tied to a rigid regime of compliance with the result of the adjudication process. A case in point is the ongoing work of the Eritrea-Ethiopia Boundary Commission (EEBC), which was established as a result of the protracted Eritrea-Ethiopian border crises and in accordance with the Algiers Peace Agreement of 12 December 2000 (Article 4). ${ }^{19}$ The EEBC delivered its 125-page verdict on 13 April 2002, after which an unusual procedure was adopted by the parties in which the EEBC was required to continue its work by demarcating the boundary but without provision for formal pleadings by the parties or full oral hearings. ${ }^{20}$ The Commission arguably ignored indications that there is deep dissatisfaction with its decision by various interest groups in both States and adopted a formalistic approach to its ongoing demarcation task, disregarding local realities. ${ }^{21}$ Similar to the Nigerian situation, the delimitation attained by the demarcators of the EEBC produced a situation whereby large numbers

18 See Continental Shelf, Tunisia/Libyan Arab Jamahirya, ICJ Reports (1982), 77, para.107. For a critique of this rigid approach to justice and a critical reappraisal of the uti possidetis principle by which many colonial boundaries remain sacrosanct, see Gbenga Oduntan, above n.7, 3, 14-16, 23. See further Judge Bola Ajibola's separate opinion in the Territorial Dispute (Libyan Arab Jamahiriya/Chad) in which he appeared to argue that it appeared as if territorial issues relating to Africa are constantly being judged from Eurocentric eyes.

19 Also referred to as the December Agreement; see UN docs S/1999/32 and S/RES/1227 (1999). See also UN $\operatorname{docs} S / 1999 / 247,250,258-260,696,731,762,789,794,857 ; S / 2000 / 389,413,421,422,430,435,437$, 568; K. Vick, War Erupts along Border of Ethiopia and Eritrea, International Herald Tribune, 8 February 1999, 2; Battles Erupt on a 3d Front between Ethiopia and Eritrea, International Herald Tribune, 9 February 1999, 2; Addis Ababa Rules Out Border War Cease-Fire, International Herald Tribune, 11 February 1999, 7; K. Vick, Ethiopians Claim Victory in Border War with Eritrea, International Herald Tribune, 1 March 1999, 8. Note also UN docs S/2000/610, 612, 619, 643, 676 and 793; S/PRST/2000/22; and S/RES/1312 of 31 July 2000, establishing the United Nations Mission in Ethiopia and Eritrea (UNMEE).

20 The Commission's Eritrea/Ethiopia Boundary (Merits), Decision on Delimitation, 13 April 2002 was followed by demarcation arrangements, paralleled by the Eritrea/Ethiopia Boundary (Interpretation) Decision of 24 June 2002, which dismissed Ethiopia's Request for Interpretation of the former Decision, as well as by the Eritrea/ Ethiopia (Interim Measures) and Eritrea/Ethiopia (Demarcation) Orders of 17 July 2002, and the Eritrea/ Ethiopia (Determinations) Decision of 7 November 2002. Copies of all of the Commission's Decisions were deposited with the Secretaries-General of the African Union (formerly the OAU) and the United Nations. For the texts and related UN Statements, see the websites of the PCA (www.pca-cpa.org) and of the United Nations (www.un.org/NewLinks/eebcarbitration). See also UN doc. S/RES/1398 of 15 March 2002, which extended the UNMEE until 15 September 2002, with a view to facilitating the implementation of the Eritrea/Ethiopia Boundary Decision; UN docs A/57/1, 2002, para.39; S/2002/744; S/RES/1430 and A/ RES/1434 of 14 August and 6 Seprember 2002, which further extended the UNMEE until 15 March 2003; and S/2002/977. See also Jon Abbink, Badme and the Ethiopian-Eritrean Conflict: Back to Square One? (2003) (www.erpic.org/Badme.html).

21 The controversy surrounding the Decision is reflected in a letter written to the EEBC arbitrators to mark the first anniversary of the verdict. It reads, inter alia: "On April 13, 2001, when the governments of Ethiopia and Eritrea announced their victory regarding their common border, thousands of Irobs woke up to find their history and their heritage suddenly altered by five judges that had never set foot in the boundary region. They were initially confused by the Commission's decision because the decision placed the term 'Irob' entirely in Ethiopia, yet numerous Irob villages and hamlets were now placed in Eritrea. They were confused as to why Ethiopia declared absolute victory because Eritrean radio stations in the Washington D.C. area and apparently in Eritrea were bragging that they won one third of Irobland. Slowly, our fears became true. It became clear that despite the many pleas made by the people of Irob, the Eritrea-Ethiopia Boundary Commission had shockingly sacrificed the people of Irob for the sake of political compromise." See Tesfamariam Baraki, Beyond the Badme Debate: The Forgotten Case of Irobland, 10 March 2003 (www.unitedethiopia.org/BeyondtheBadmeDebate.html). 
of people were cut off from their rivers, farms and other means of livelihood. Despite this fact, the EEBC stated in paragraph 14A of the Commission's Demarcation Directions of 8 July 2002 that with respect to the division of towns and villages:

The Commission has no authority to vary the boundary line. If it runs through and divides a town or village, the line may be varied only on the basis of an express request agreed between and made by both Parties. ${ }^{22}$

The written comments submitted by Ethiopia on the draft of this provision had expressed the hope that it could be made more flexible so that demarcations could be more practical and mitigate hardships. The Commission, however, rejected this suggestion, largely based on the expectation that aggrieved States must still respect the finality, which the parties had agreed to attach to the Delimitation Decision. This is, however, difficult to reconcile with the Commission's view that:

A demarcator must demarcate the boundary as it has been laid down in the delimitation instrument, but with a limited margin of appreciation enabling it to take account of any flexibility in the terms of the delimitation itself or of the scale and accuracy of maps used in the delimitation process, and to avoid establishing a boundary which is manifestly impracticable. ${ }^{23}$

Despite this and perhaps with the full realization that getting the parties to jointly request that a line should be varied in the interest of protecting the citizens of either party would be very unlikely to say the least in a dispute with such a difficult and long gestation period, the Commission seems to have determined a priori that there would be no need for it to be flexible in its work because it is "not of the view that there is to be derived from that practice a settled rule of customary international law to the effect that demarcators not so expressly empowered nonetheless possess such power". ${ }^{24}$ In other words, it is reasonable to expect that the ongoing demarcation would suffer from the same rigidity and commitment to formalism that typified the delimitation stage and has exposed the Commission's work to the strongest criticism by all sides to the dispute and by other commentators. It is suggested that the Commission's work would have better chances of success had it adopted the more holistic view of the entire exercise as a process.

22 Eritrea-Ethiopia Boundary Commission, Observations, 21 March 2003, published as an addendum to the Progress Report of the Secretary-General on Ethiopia and Eritrea, UN doc. S/2003/257 of 6 March 2003 (www.pca-cpa.org/PDF/Obs.EEBC.pdf).

23 Ibid.

24 Ibid., 2-3. In classic and unrelenting fashion symptomatic of the conservative jurisprudence of the main international courts and tribunals, it is stated that "the Commission is, as already noted, constrained by the terms of the December 2000 Agreement. The Commission is unable to read into that treaty language, either taken by itself or read in the light of the context provided by other associated agreements concluded between the Parties, any authority for it to add to or subtract from the terms of the colonial treaties or to include within the applicable international law elements of flexibility which it does not already contain." This is very difficult to reconcile with paras 1 and 2 of Eritrea/Ethiopia Boundary (Determinations), above n.20. 
The parties reiterated very early in their negotiations their undertaking to respect the rights of the populations of the other country residing in the affected areas and to afford them full protection in accordance with international law. ${ }^{25}$ When Nigeria raised the issue of implementing a Protocol for the protection of the rights of the affected populations in the Lake Chad Area which it had presented during the sixth meeting of the Mixed Commission in Abuja, Cameroon refuted such plans and stated that the issue should be addressed within the framework of the Cameroon-Nigeria Joint Commission. Eventually, the Nigerian delegation agreed to refer this issue to the Cameroon-Nigeria Joint Commission (a body far removed from the boundary demarcation negotiations). ${ }^{26}$ The problem with such a compromise and indeed such stance is that those demarcating the boundaries are bereft of substantial basis to act equitably in the field and in the interest of the affected population.

The Sub-Commission on affected population has endeavored to reduce the deleterious effects of the anticipated demarcation by conducting several field trips to most of the villages and communities along the land boundary in order to ascertain their views and to anticipate the challenges that they would face as a result of the delimitation and demarcation; there is nothing, however, in the Court's judgment to suggest that it is incumbent upon the parties to ensure that straddling communities ought to be left after demarcation as a single organic unit. In the main, the traditional and local authorities as well as the general populace on both sides of the boundary have predominantly expressed support and appreciation for the efforts of the United Nations and the leadership of the two countries in their persistent quest for peaceful prosecution of the Court's judgment. This is despite the fear that in villages such as Narki ceded to Cameroon by the ICJ delineation line, the populace may have their farms remaining in Nigeria.

It is perhaps important at this stage to advance certain criteria by which the demarcation of straddling villages may be resolved. The extent to which a settlement straddles the State(s) in question would naturally differ from case to case. Rarely will the straddling village/ community or city be geometrically spread equally over the territories involved because human settlements as organic phenomena rarely have such natural symmetry. A straddling settlement may therefore "straddle" with respect to one of the territories with only a few dozen houses, houses or homesteads. It is suggested that permanence of the structures that straddle into foreign territory would be a relevant factor in the consideration of the rights and interests of the affected people and States in the search for an equitable solution.

Where only tents, caravans or other moveable architectural structures are at issue, especially where they are few, it may be suggested that a court can afford to carry out a delimitation exercise in a much stricter fashion de minimis non curat lex. It may, however, be that

25 Paragraph 7 of the Communiqué Adopted at the First Meeting of the Cameroon-Nigeria Mixed Commission Established Pursuant to the Joint Geneva Communiqué of 15 November 2002 (Yaoundé, 1 -2 December 2002); above n.4.

26 Paragraph 3 of the Communiqué Adopted at the Seventh Meeting of the Cameroon-Nigeria Mixed Commission Established Pursuant to the Joint Geneva Communiqué of 15 November 2002 (2-3 December 2003); see also para. 6 of the Communiqué Adopted at the Ninth Meeting of the Cameroon-Nigeria Mixed Commission Established Pursuant to the Joint Geneva Communiqué of 15 November 2002 (7-8 April 2004); above n.4. 
a straddling settlement straddles not by virtue of human habitation, but by virtue of the fact that the farmland or other economic or vital resource such as a river upon which the human settlement depends is to be found within the territory of another State. In such cases, the appurtenance and close geographical relation to the human settlement, the crucial importance of the resources, the length of time that the settlement has spread into foreign territory as well as other "effectivite"'-oriented criteria would all be relevant facts. ${ }^{27}$ In such cases, there is a strong basis for the exercise of judicial discretion to vary the line in the interest of human justice, even where no single dwelling is at issue. It is argued that this view is supportable, especially where there is no adjacent settlement that competes for the use of the river or fertile land on the other side. Where significant economic resources are at stake, such as oil and gas or fisheries, it is suggested that the issue is no longer that of merely protecting the indigenous people and the territorial State into which the settlement has spread ought to retain full rights over such resources.

In relation to fisheries, the recognition of artisanal fishing rights is a favoured option. The jurisprudence of the ICJ in relation to fishing rights of indigenous population reveals that the Court is indeed sensitive to the duty upon it to preserve the livelihood and interests of indigenous populations affected by its judgments. In relation to maritime disputes, the Court strictly construes its delimitation tasks but has always strongly expressed in its jurisprudence a regime of jointly exercised fishing rights. It is this sort of specificity that ought to be introduced to the language of the Court's judgment in deciding upon straddling villages. ${ }^{28}$

27 Note should be taken that effectivité remains a potent consideration in the determination of boundary and territorial issues, despite the Court's disregard of the principle in the Cameroon-Nigeria case. This conclusion is clear from the Court's conclusion in the Frontier Dispute (Burkina Faso/Republic of Mali) case that "where the territory which is the subject of the dispute is effectively administered by a state other than the one possessing the legal title, preference should be given to the holder of the title. In the event that the effectivité does not co-exist with any legal title, it must invariably be taken into consideration" (emphasis added), Frontier Dispute (Burkina Faso/Republic of Mali) 586-587, para.63, above n.2.

28 In the Kasikili/Sedudu Island case (Botswana/Namibia) Judgment of 13 December 1999, the Court stated that "the nationals of Namibia, and vessels flying its flag, are entitled to, and shall enjoy, a treatment equal to that accorded by Botswana to its own nationals and to vessels flying its own flag. Nationals of the two States, and vessels, whether flying the flag of Botswana or of Namibia are, therefore, subject to the same conditions as regards navigation, fishing and environmental protection", Fisheries Jurisdiction Case (Merits) (United Kingdom v. Iceland) Judgment of 25 July 1974. Iceland was held bound to an Exchange of Notes of March 1961, which in effect granted British fishing boats the rights to operate in waters outside the 12-mile exclusive fisheries zone pronounced in Iceland's Althing Resolution of 5 May 1959 (see para.79). Case of the Maritime Boundary Delimitation between Eritrea and Yemen (Eritrea v. Republic of Yemen) Award of 17 December 1999: "It was concluded that the traditional fishing regime "is one of free access and enjoyment for the fishermen of both Eritrea and Yemen' (para. 101). The Tribunal added that Eritrea may act for its nationals through diplomatic contacts with Yemen or resort to adjudication." Case concerning the Maritime Delimitation and territorial questions between Qatar and Bahrain (merits) (Qatar v. Bahrain) Judgment of 16 March 2001: "The Court refused to consider the existence of pearling banks as forming a circumstance which would justify an eastward shifting of the equidistance line as requested by Bahrain, even though the pearl banks were predominantly exploited in the past by Bahraini fishermen" (para.32). Anglo-German Agreements of 11 March and 12 April 1913: "The fishing rights of the native population of the Bakassi Peninsula in the estuary of the Cross River shall remain as heretofore" (Art.26). "Where the boundary is formed by rivers, the populations on both banks shall have equal rights of navigation and fishing. By virtue of this provision, all maritime and riverine areas of the entire boundary as delimited in the Agreement constitute common fishing grounds to the native population" (Art.29). 
Where just few compounds or farmlands spread into another territory, a court may decide not to treat this as an instance of the existence of a straddling settlement and strict delimitation may be exercised. Boundary demarcators in such cases may also adopt a strict adherence to the delimitation line. Where an international court has not exercised discretion along the lines suggested above and this would lead to manifest injustice to a significant population, there is much credence for the view that those charged with the implementation of the judgment should seriously explore possibilities of ameliorating the harshness of the delimitation. $^{29}$

The centre of the village, the location of its religious places (such as shrines mosques, churches, ancestral groves), the palace of the king or chiefs (in the case of the affected Cameroon-Nigeria boundary villages, the Bullama) or its oldest quarter may be a useful indication of which State may claim ownership but these features do not offer conclusive evidence of the ownership of one State or the other to the extent that the people themselves may consider themselves to be rightfully the citizens of another State in spite of where the centre of the village or its oldest parts lie. It is indeed not inconceivable that villagers may move around frequently, creating confusion as to where the origins of the village or settlement began and where the locations of the many places mentioned above actually were. Natural causes (war, drought, landslides, earthquakes, infestation by locusts, wildlife, etc.) may cause a settlement to shift around in such a way that it becomes difficult if not impossible to determine the pattern of spread of a straddling settlement.

It is for this reason that the oral history of the particular people and their wishes as may be determined by consultation and plebiscites are crucial factors to be taken into consideration by demarcators. It is also for this reason that a court that is without close knowledge of the people and places involved or has not received extensive evidence on a straddling community must hesitate to prescribe a delimitation that definitively splits the community. It is the position of this paper that those that are entrusted with the function of delimitation in fact have the power if not a duty in the exercise of that function (barring an express and specific limitation by the parties to the contrary) to consider the wishes of the affected people in a straddling settlement and other factors such as the previous history of administration and to vary the line of delimitation in the overall interest of human justice. It hardly needs be mentioned that the exercise of this function in any delimitation exercise must be used within very strict limits. It is not also beyond contemplation that after consultation, the people of a straddling settlement may not be opposed to a strict division along treaty lines, especially where the treaties concerned have an unquestionable legitimacy in the estimation of the people. The important consideration, however, is that diligent consultation with the concerned population is a desirable task of a delimiting tribunal and a central task of the demarcation team.

29 Note should, however, be taken that the discussion so far is in relation to straddling villages the sovereignty over which is not dispute. A dispute over the determination of which State can lay claim to a straddling settlement as a whole is a territorial dispute and not a boundary dispute. 
It is suggested that the power to vary the delimitation line around straddling settlements must be exercised very carefully and is justifiable upon the existence of certain conditions:

(a) The exercise of this power is pleaded by one of the States involved and there is a finding that there is indeed a straddling community in existence.

(b) The exercise of this power is pleaded by the affected people and the request is not opposed by at least one of the States involved and there is a finding that there is a straddling community in existence.

(c) There has been no express and specific limitation by the parties that this power may not be exercised.

(d) The exercise of the power is fair, just and equitable in view of the overall circumstances and merits of the case.

(e) The ownership of the straddling settlement is not judged by the Court to be the central dispute between the parties. ${ }^{30}$

Relevant factors that will determine the extent to which such discretion may be exercised include the relative size of the States facing the boundary dispute. In the case of relatively large States such as Cameroon and Nigeria, the varying of a line of delimitation by a few dozen metres is good policy if it can keep settlements together where the people and at least one of the States involved are desirous of that result. Justification for this position exists in the annals of jurisprudential thinking and practice.

The fifth condition mentioned above perhaps deserves further explanation. It refers to the need to make a distinction between a settlement that forms part of the central dispute between the litigating States and those which are only to be dealt with as a consequence of the general task put before a court or tribunal. Thus, disputes over territories such as Bakassi peninsula (Cameroon-Nigeria dispute) and Badme (Eritrea-Ethiopia dispute) would not necessarily fall within the scope of the argument presented here. In reality, the entire frontier between two States may be drawn into issue whereas only specific places are crucial to the dispute between the two States. While the Court must apply all due diligence in its work of delimiting the boundaries between the two States, it is clear that varying the line with respect to small straddling villages in the interest of human justice, especially in those areas outside Lake Chad and Bakassi Peninsula, was arguably a desirable consequence of its work, especially in situations where both States stood to potentially gain from this approach. Courts of law should be held to a higher requirement and standard of justice which go beyond the demands of the litigating States. An institution that arbitrates or

30 This particular distinction in relation to the Cameroon-Nigeria dispute is perhaps discernible in the way in which the dispute unfolded before the Court. On 29 March 1994, Cameroon filed the suit against Nigeria and defined it as "relat[ing] essentially to the question of sovereignty over the Bakassi" (paras 1 and 25(a)). Later, on 6 June 1994, Cameroon filed in the Registry of the Court an additional application "for the purpose of extending the subject of the dispute to a further dispute" described in that Additional Application as "relat [ing] essentially to the question of sovereignty over a part of the territory of Cameroon in the area of Lake Chad" (para.3). Cameroon then also requested the Court, in its Additional Application, "to specify definitively" the frontier between the two States from Lake Chad to the sea, and asked it to join the two Applications. It is arguable that a pecking order may be established as to the crucial areas in dispute. 
adjudicates matters between sovereign States is first and foremost an international temple of justice and is no way obliged to maintain a strictly positivist approach in the execution of its tasks in the face of the possibility of putting in jeopardy human and generational rights of indigenous peoples. ${ }^{31}$

Apart from the above suggestions, it would be useful to examine how this problem has been solved in similar situations in the past and to see whether any of this could also be helpful in developing solutions for the present Cameroon-Nigeria negotiations as well as in situations that may emerge in the future.

\section{Alternative models for the Cameroon-Nigeria straddling villages}

\section{IV.A. International models}

It may be noted that in early modern Europe, when national borders in the modern sense first began to be established, non-contiguous and perforated nations were commonplace. According to the conception of the shapes of nations that is currently preferred, however, nations must conform to what may be referred to as the topological model of (approximate) circularity. In other words, borders must guarantee contiguity and simple connectedness, and such borders must as far as possible conform to existing topographical features on the ground. ${ }^{32}$ However, not only are there successful and long-lasting multicultural and multiethnic societies involving systematic overlapping and intermixing of distinct groups within a single region, there are also and indeed far more commonly than is often presupposed noncontiguous nations (such as the United States) whose sovereign territory is broken up into separate pieces by the interspersed territory of other sovereign nations.

Possibly the most complicated case of straddling villages and enclaves outside Africa that practitioners refer to is the cluster of villages and settlement on the Belgium-Netherlands frontier. Belgium became independent from the Netherlands in 1830 (although not

31 It is notable that the ICJ approach in this matter is in no way different from the general attitude of other international courts. The refusal of international courts and international law practitioners to adopt a more flexible approach to the resolution of disputes noted by older authorities like Han Morgenthau (in relation to the Permanent Court of International Justice (PCIJ)) remains unchanged to date. Morgenthau regretted the predominance of "time-honoured pseudo-logical method of traditional positivism which prevailed in the jurisdiction of the domestic supreme courts at the turn of the (19th) century" (parentheses added). He wrote "resistance to change is uppermost in the history of international law. All the schemes and devices by which great humanitarians and shrewd politicians endeavoured to reorganize the relations between states on the basis of law, have not stood the trial of history. Instead of asking whether the devices were adequate to the problems which they were supposed to solve, it was the general attitude of the internationalists to take the appropriateness of the devices for granted and to blame the facts for the failure", Hans J. Morgenthau, Positivism, Functionalism, and International Law, 34 American JIL (April, 1940), 260, 263. See also generally Wild, What Is the Trouble with International Law? Vol.XXCII, APSR (1938).

32 The striving to conform to this model can be seen at work today in Quebec and in Ireland; it underpins much of the rhetoric of the PLO, and was certainly, to some degree, a motivating factor in much of the ethnic cleansing which took place in Bosnia in recent times. See Barry Smith, The Cognitive Geometry of War, in: Peter Koller and Klaus Puhl (eds), Current Issues in Political Philosophy (Vienna, Hölder-Pichler-Tempsky, 1997), $394-403$. 
recognized by the Netherlands until 1839). By treaty, Belgium was to consist of the entirety of several of the Dutch provinces, plus the described halves of two others (Limburg and Luxemburg). The village of Baarle was one of the most difficult to deal with. Baarle belonged partly to the province of Antwerp (falling to Belgium) and that of North Brabant (which remained Dutch). In the early 1840s, a boundary commission concluded the impossibility of drawing a continuous line through/around Baarle because of the unique dictates of historical and social circumstances (including feudal arrangements dating back to c. 1200) which made the village and its outlying hamlets contain numerous enclaves and counter-enclaves belonging to both nations. In the end, to circumvent the real difficulties, the main boundary as described in the treaty stopped at the edge of the municipal boundary on the east, and resumed from the edge of the municipal boundary on the west. For the intervening land, i.e. the municipalities of Baarle-Hertog (Belgian) and Baarle-Nassau (Dutch), a cadastral map was drawn up and all 5732 land parcels were individually ascribed to either Belgium or the Netherlands on the basis of traditional appurtenances in particular regard to whom they had paid their land tax. The main boundary was not formally delimited until 1974, partly inspired by a 1959 case before the ICJ. The Court determined that Belgium had sovereignty over one of the enclaves, which the Dutch had contested. The enclaves themselves were eventually delimited to 1-centimetre accuracy, with a turning point every 30 metres on average, in 1995. There are presently a total of 22 Belgian enclaves, and eight Dutch enclaves, of which seven are counterenclaves within the Belgian ones.

According to this model, therefore, Cameroon and Nigeria could attempt an honest assessment of which parts of the existing villages they actually control by means of allegiance and various acts of administration and divide the villages along such lines, even if it would lead to the existence of enclaves and counter-enclaves. Although such a regime may be foreseeable in the event of complete deadlock over a binary demarcation regime for one or more of the straddling villages in the current Cameroon-Nigerian demarcation exercise, it must be stated expressly that this model may be less than ideal, for a combination of at least three reasons. First, it would ignore in totality the delimitation achieved by the Court. Secondly, it would lead to a discontinuous demarcation of the boundary in a way completely unfamiliar to African States and their largely illiterate and/or rural populace that occupies border areas. This would probably lead to more confusion and tensions among the ethnic groupings. ${ }^{33}$ Thirdly, it would ignore existing maps, which have been drawn so far without substituting them with an alternative that is practical and certain to last.

33 African statesmen indeed readily acknowledge the peculiar problems that the continent faces. Mr Chukwuemeka Chikelu, the Nigerian Information and National Orientation Minister, recently identified "inequality, poverty, corrupt leadership as well as lack of communication as the cause of conflicts and wars in African countries". Accordingly, he cautions that unless Africa managed its conflicts wisely, it would perpetually remain behind the other continents. See Wale Igbintade, Why Africa Has Conflicts, Minister Vanguard, Wednesday, 13 August 2003. 


\section{IV.B. The enclave solution}

Some writers ${ }^{34}$ on boundary issues adopt a forward-looking and optimistic approach to boundary delimitation and demarcation problems and recommend that States should embrace the concept of non-continuous nations. ${ }^{35}$ Although the concept of enclaves is slightly different in many respects from straddling villages per se, it is relevant to consider their proposal, for two reasons. First, straddling villages do not always run continuously in one geometric portion and may indeed consist of portions which have broken off and fall well into the territory of the neighbouring country. Secondly, this method may be used to reconcile the difficulties of giving effect to the Court's judgment requiring the exchange of over 50 villages between Cameroon and Nigeria. Thus, there would be no need for voluntary or forcible transfers of affected populations.

The existence of enclaves, i.e. pieces of territory of one country (the home State) embedded inside another (the host State), is well recognized by many. However, few people recognize the fact that there are currently about 258 enclaves (including approximately 32 counter-enclaves

34 One central argument of this group is that there are different types and principles of proximity. The simplest type of proximity is spatial, and although conceiving and drawing boundaries on the basis of spatial proximity can yield benefits in terms of efficiency and community (as well as benefits of a military or security character, where these are relevant), there are many cases in human history in which spatial proximity has been overridden by other types of proximity. Expansion of electronic communication in modern times brings about an entirely new sort of proximity. The principle of proximity for Australians was for a long time Anglo-Saxon culture ("Home"). This arguably is now gradually being replaced by emphases on geographical proximity and economic effectiveness with Asia. It is not only for the cause of spatial proximity that wars are fought. This school of thought believes that States should learn to cope with different types and principles of proximity so as to avoid war and bitter conflicts in the future. See Barry Smith, above n.32, 403; B. Whyte, Bordering on the Ridiculous? A Comparison of the World's Two Most Complex Boundaries: The Belgo-Dutch Enclaves at Baarle and the IndoBangladeshi Enclaves at Cooch Behar, 53, The Globe (2002), 43-61; B.R. Whyte, Waiting for the Esquimo: An Historical and Documentary Study of the Cooch Behar Enclaves of India and Bangladesh, PhD thesis, published as Research Paper No.8, by the School of Anthropology, Geography and Environmental Studies, Melbourne, University of Melbourne (2002); Kolnai, Aurel, Les ambiguités nationales, La nouvelle Relève, Montreal (1946), 5, 53346, 6, 644-55; Mark Monmonier, How to Lie With Maps (Chicago and London, The University of Chicago Press, 1991); Barry Smith, Fiat Objects, in: N. Guarino, L. Vieu and S. Pribbenow (eds), Parts and Wholes: Conceptual Part-Whole Relations and Formal Metrology, 11 th European Conference on Artificial Intelligence, Amsterdam, 8 August 1994 (Amsterdam, European Coordinating Committee for Artificial Intelligence, 1994), 15-23; Ralph B. Taylor, Human Territorial Functioning: An Empirical, Evolutionary Perspective on Individual and Small Group Territorial Cognitions, Behaviors and Consequences (1988).

35 Writers in this group tend to have a scientific background, usually in geography. It is probably interesting to note that scientists more than lawyers and politicians tend to adopt very practical and often more imaginative ways of viewing boundary disputes. They tend to focus on boundaries as meeting points of nations rather than lines of strict divisions. A view holds it that scientists, eager to carry out their work in Antarctica without political constraint and for a common goal of increased knowledge, outwitted statesmen, politicians and diplomats during the early stages of the development of the law governing Antarctica. Territorial ambitions, which would either have been a free-for-all fight, as in 1959, were drowned in the euphoria created by the International Geophysical Year (IGY)_ "a triumph admittedly of the spirit of co-operation among scientists of the world". See Ramantullah Khan's review of Wolfrum's work: Ramantullah Khan, Book Review, 25 Indian JIL (1985), 362. In an interesting submission reflecting a deliberate effort to discourage governmental interest, a certain Dr Gould stated to the US Committee on Foreign Relations in 1960: "My profession is geology and I would not give a nickel for all the mineral resources in Antarctica." See G. Triggs, International Law and Australian Sovereignty in Antarctica (1986), 207. 
plus one counter-counter-enclave) in the world. ${ }^{36}$ There are thus more enclaves than countries. Alaska is separated from the rest of the continental United States by Canada. The division of Switzerland into cantons was unconstrained by rigid geometry. ${ }^{37}$ Switzerland itself is described by many as perforated in that it circumcludes inter alia the German town of Büsingen on the Rhine, so that citizens of Büsingen who work in Germany find themselves traversing through different national borders on their journey to and from work. The Campione d'Italia is a similar isolated enclave of Italy, surrounded entirely by Switzerland. There are 38 such enclaves (exclaves: see Catudal 1979) between Belgium and Holland in Baarle, and the Spanish commune of Llívia in the Cerdanya region of Catalonia is entirely surrounded by France.

Rights of access can be guaranteed by treaty in these situations. Writers supporting this view point to the existing regime of rights of access to embassies which currently exist throughout the globe and which have been successfully guaranteed by treaty for many generations. ${ }^{38}$ Other examples include the unimpeded communications between Alaska and the

36 There are 32 enclaves plus seven counter-enclaves in Western Europe, as follows: Netherlands: one enclave plus seven counter-enclaves (Baarle-Nassau in Belgium); Belgium: 22 enclaves (Baarle-Hertog in the Netherlands); Germany: five (Vennbahn enclaves at Rötgen/Monschau in Belgium); Spain: one (Llivia in France); Germany: one (Büsingen in Switzerland); Italy: one (Campione d'Italia in Switzerland); Austria: one (point connection) (Jungholz in Germany). The break-up of the former United Soviet Socialist Republic has led to a rash of enclaves in that region. Presently, there are at least 15 examples of this: Russia: one enclave (San'kovo/Medvezh'e in Belarus); Armenia: one (Bashkend in Azerbaijan); Azerbaijan: two (Upper Askipara and Barkhudarly in Armenia); Azerbaijan: one (Kiarky (north of Nakhichevan) in Armenia); Azerbaijan: two (unnamed (south of Tatly) in Armenia); Tajikistan: one (Sarvaksoi/Sarvaki-bolo in Uzbekistan); Tajikistan: two (Vorukh and "Kairagach" in Kyrgyzia); Uzbekistan: two (Kalacha, Sokh in Kyrgyzia); Uzbekistan: two (Dzhangail' and Shakhimardan/Iordan in Kyrgyzia); Kyrgyzia: one (Barak in Uzbekistan). Asia has a staggering 178 enclaves, 25 counter-enclaves plus one counter-counter-enclave and accounts for about $80 \%$ of the world's known enclaves. They are: Cyprus: four enclaves (i.e. UK's Dhekelia Sovereign Base, Dhekelia power station (2), Ormidhia and Xylotymbou); Oman: one (Madha in UAE); UAE: no enclaves plus one counter-enclave (Nahwa in Oman); India: 102 enclaves plus three counter-enclaves plus one counter-counter-enclave (the Cooch Behar enclaves in Bangladesh); Bangladesh: 71 enclaves plus 21 counter-enclaves (Cooch Behar enclaves in India). For a clearer tabulation of the above, see Table 1 and Figures $1-3$ accompanying Whyte, above n.34, 7-60.

37 The Swiss Canton of Fribourg contains several portions which are completely surrounded by the Canton of Vaud, which is, like several other cantons, a perforated spatial object. The Swiss are said to have learned that borders can be oddly shaped and that the exploitation of bizarre shapes can be a way of doing justice in peaceful fashion to inherited religious, linguistic, ethnic or dynastic divisions.

38 Problems which may be easily removed through such a regime include the crucial problem posed by resident permit requirements of Cameroon regarding all foreigners including the Nigerians who would fall into its territory as a result of the implementation process. Similarly, the difficulties that may be envisaged regarding Cameroonians who fall into Nigerian territory with respect to obtaining Nigerian identity cards and the resultant benefits and duties could be avoided if enclave options are negotiated. For pre-existing regimes of international easements, note the judgment of the ICJ in the Right of Passage case (below n.74). Note also the case of Moresnet, which existed from 1816 to 1919 , as a tiny European mini-State of about $3.5 \mathrm{~km}^{2}$. Moresnet existed solely because its two large neighbours couldn't agree on who should own it, and they decided therefore to make it a neutral territory where both would share control equally. It was located some $7 \mathrm{~km}$ southwest of Aachen, directly south of where the borders of Germany, Belgium and the Netherlands intersect on the Vaalserberg. Could this type of solution be what the Court had in mind with respect to the straddling villages it referred to expressly in the judgment? See further Gordon E. Sherman, Neutrality of Switzerland, 12 AJIL (1918), 789; Gorden Sherman, Book Review, 12 AJIL (1918), 214; Reply of the Allied and Associated Powers to the Observations of the German Delegation on the Conditions of Peace, 6 International Conciliation (1919), 1360. 
United States. The Vance-Owen Peace Plan involved the establishment of an "International Access Authority" to guarantee freedom of movement in Bosnia. ${ }^{39}$

\section{IV.C. African models}

Interestingly, Africa has so far produced a lesser number of controversies in relation to straddling villages. Only further research can reveal whether this is because the existence of straddling villages and de facto enclaves is largely ignored by governments in the light of other pressing economic and political problems or perhaps this is as a result of the relative recentness of the making of African boundaries (i.e. primarily since the partitioning of Africa at the Berlin Conference in 1885). ${ }^{40}$ It is perhaps significant that there are no examples of enclaves in the classical sense (i.e. territory belonging to one State in the foreign territory of another) in Africa at all. Indeed, enclaves exist on only two continents: Europe and Asia. ${ }^{41}$ Africa is, however, host to at least one successful case of complete enclosure of one State in another. Reference is here made to Lesotho's existence as an enclave inside South Africa. ${ }^{42}$

The pattern that reveals itself so far is that African States hesitate to dissect settlements into two during boundary demarcation, despite the contents of the delimitation instrument.

39 The International Access Authority was planned to ensure that full freedom of movement shall be allowed throughout Bosnia and Herzegovina (and the Republic of Croatia and to the Republic of Serbia) to be ensured in part by the maintenance of internationally controlled throughways. See Interim Arrangements for the Implementation of the Union of Three Republics, 28 June 1993, A Coordination Body (http://sca.lib.liv.ac. uk/collections/Owen/lists/owencd3.html). Indeed, Barry Smith believes that "[h]ad the Vance-Owen Plan been put into effect in Bosnia in 1992 (and had it succeeded) it would have saved 200,000 lives". See Smith, above n.32.

40 The General Act of 26 February 1885. The mid-nineteenth century marked the beginning of the renewed interest in the continent of Africa by the imperialist powers of Europe. Of particular interest to them at the time were the hitherto unexplored central African regions, comprising modern-day Zaire, Zambia and Zimbabwe. This interest was based on the relentless rush for raw materials and investment that these territories provided for Europe's continuing industrialization. Competition between the European powers was severe, as they coveted the opportunities that colonial subjugation assured. Much interest was concentrated on the Congo region (modern Zaire) upon which King Leopold II of Belgium had set his sights (it later turned out to be a lucrative source of rubber). However, the old colonial nation of Portugal, with African interests in Angola and Mozambique extending back over three centuries, also saw the Congo region as its historical sphere of influence. International rivalry and diplomatic conflicts between the principal European powers prompted France and Germany to suggest the notion of a European conference to resolve contending claims and provide for a more orderly "carving up" of the continent. The Conference met at Berlin from November 1884 through February 1885 and resulted in the following agreement: The Berlin Act of 1885. The participating States that sent representatives were Austria-Hungary, Belgium, Denmark, France, Germany, Great Britain, the Netherlands, Portugal, Russia, Italy, Spain, Sweden, Turkey and the USA. (For further reading on the history of this period and a summary of the General Act of 26 February 1885, visit http://web.jjay.cuny.edu/ jobrien/reference/ob45.html.)

41 In the main, these have a feudal origin and date back several hundred years; Whyte, above n.34, 43.

42 Note, however, that this is a different legal and political situation from the cases discussed below relating to enclaves of independent States that are planted in another (usually neighbouring) State. Note also the 10 self-governing territories for different black ethnic groups which were established as part of the apartheid policy of the erstwhile apartheid South Africa. Four of these were granted "independence" by the infamous South Africa regimes (although they were recognized only by South Africa and each other). These former South Africans Homelands or Bantustans ceased to exist on 27 April 1994 and were re-incorporated into South Africa, and all were absorbed into the new provinces. 
Where the main path of the boundary is parallel to a road or along a meridian/parallel, it is diverted around villages which otherwise straddled the boundary. A good instance is the Benin/Nigeria at $10^{\circ} \mathrm{N}$, which has semi-circular offsets to let Nigeria retain villages along the road the boundary follows. Similarly, the Ghana/Burkina Faso boundary along the $11^{\circ} \mathrm{N}$ parallel between $1^{\circ} \mathrm{W}$ and the Red Volta River was demarcated by rectangular offsets in order to leave straddling villages to either country. ${ }^{43}$ As a result of the dependence of African traditional societies on communal or customary lands and property, there is also the problem of straddling customary lands recognized by the customary communities but ignored or disputed by the States Parties. This issue, however, is yet to receive the academic attention it deserves in African legal jurisprudence.

As a general rule, however, it would appear that African States are more inclined towards the view that "good fences make good neighbours" and would, in the event of boundary demarcation, adopt a clear boundary demarcation which leaves whole communities and villages intact. It is possible to argue that non-separation of existing communities would be more likely where the demarcation does not follow military hostilities and protracted litigation, as was unfortunately the case in the recent history of Cameroon and Nigeria. It is for this reason that the issues surrounding straddling villages have to be handled with much care and with reasoned diplomacy.

The enormity of the task before the parties and indeed the UN facilitators must not be underestimated. The implementation of the ICJ decision is a desirable end in itself but a close eye must be placed on the larger picture in light of past experiences on the African continent. Guinea, Liberia and Sierra Leone continue to trade accusations of boundary incursions (some involving aerial raids) and many civilians have lost their lives, ${ }^{44}$ abductions have taken place along the Angolan-Namibian border and aid-workers are not spared violence. ${ }^{45}$ Similar problems exist between Chad-Sudan, Mali-Mauritania, ${ }^{46}$ BurundiTanzania, Equatorial Guinea-Gabon, Eritrea-Sudan and Ethiopia-Kenya. ${ }^{47}$ Togolese rebels create refugee problems for Ghana by shelling border villages; the Sudanese Lord's Resistance Army frequently attacks Ugandan border villages. It is necessary to note that in the African experience, the end of judicial and arbitral proceedings in relation to boundary conflicts does not indicate the end of the danger to the affected population. For instance, the

43 Maps and descriptions of the boundary treaties can be found in Ieuan Griffiths, The Scramble for Africa: Inherited Political Boundaries, 152 Geographical Journal 2 (1986), 204-16, especially 207-8. For the Ghana/ Burkina boundary, see the Russian 1:200,000 map C-30-xii (http://sunsite.berkeley.edu/EART/ghana/ $200 \mathrm{k} / 03-30-12 . j \mathrm{pg}$ ).

44 BBC Online, Guinean forces shoot Liberian Helicopter, Wednesday, 18 October 2000 (http://news.bbc.co.uk/ 2/hi/africa/977835.stm).

45 BBC Online, Hundreds killed in Guinea attack, Thursday, 7 December 2000 (http://news.bbc.co.uk/2/hi/ africa/1059818.stm).

46 Joe Bavier, Chadians Concerned over Growing Tensions with Sudan, Voice Of America, 28 December 2005 (www.voanews.com/english/2005-12-28-voa35.cfm).

47 Troops Deployed on Border, Kenya Times, 25 March 1999 (FBIS-AFR-1999-0325). 
Ethiopia-Eritrea border situation remains volatile and dangerous to the population therein, despite the 2002 award of the Eritrea-Ethiopia Boundary Commission. ${ }^{48}$

With these factors in mind, nothing less than a sensitive implementation of the ICJ decision is required and the parties ought not to be limited by a slavish attitude to judicial decisions. At any rate, Cameroon and Nigeria have conducted themselves quite commendably since the 2003 decision and ought to be trusted with the ability to develop situation specific solutions that have a better chance of long-lasting resolution of all foreseeable conflicts. Both States would be eager to avoid certain identifiable "bad practices" found in international relations. This includes the creation of impenetrable barriers, ${ }^{49}$ inordinate creation of visa regimes, ${ }^{50}$ the use of armed village militias ${ }^{51}$ and intermittent exchange of gunfire at frontier positions. ${ }^{52}$

48 VOA News, UN: Ethiopia-Eritrea Border Remains Potentially Volatile, 29 December 2005 (www.voanews. com/english/2005-12-29-voa43.cfm). It must, however, be stated that although there were problems in some sectors, the pre-existing fraternity between Cameroonian and Nigerian communities along the land boundary can be put to good effect and consolidated upon if the demarcation process is successfully handled. Children from the boundary communities attended schools that are based in the neighbouring country without let or hindrance and farmers relied on regular vaccination of their livestock from whichever State was close enough. In 2004, some 17,000 Nigerian refugees were reported to have fled ethnic conflicts between pastoralists and farmers in 2002 and found refuge in Cameroon, where many of them still reside. See the discussion of Nigeria's transnational issues in The World Fact Book (www.cia.gov/cia/publications/factbook/geos/ni.html).

49 On 9 January 1999, the State government of West Bengal (India) set the target of fencing $900 \mathrm{~km}$ of the border with Bangladesh; $500 \mathrm{~km}$ out of the total of $1600 \mathrm{~km}$ had been fenced with barbed wire, with central government funding. The West Bengal State government also favoured the creation of a 150-mile "no man's land", affecting 450 villages in the border area, in its attempts to stem the influx of migrants from Bangladesh. India is currently building a fence along its 4,000-km (2,500-mile) border with Bangladesh. See Border Tense Over Push-In, Fence Erection Bids by BSF, New Age Dhaka, Sunday, March 62005 (www.newagebd.com/2005/mar/06/ front.html); M. Rama Rao, India's Interior Ministry Favours Fencing More Stretches of Border with Bangladesh, Asian Tribune New Delhi (www.asiantribune.com/show_news.php?id=11656). The Russian border with Estonia was also fortified with watchtowers and barbed wire, presenting problems among people who were accustomed to moving freely across the border. Estonian-Russian Border Troubles, The Baltic Observer, 13 March 1994, 5. It may be noted that despite the long history of enthusiastic self-preservation strategies and irredentism that are available in human history at least within the last century, the idea of boundary fences and walls between States has not retained any appreciable acceptability in law and public perception.

50 Witness the introduction of the visa regime between Russia's Baltic enclave of Kaliningrad and its neighbouring States with which it had coexisted in peace prior to their joining the European Union. Russia Criticizes Visa Regime between Kaliningrad, Neighbouring States, Peoples Daily Online, Tuesday, June 112002 (http:// english.people.com.cn/200206/11/eng20020611_97585.shtml). Similarly, a visa regime was introduced for persons travelling between Russia and Poland on 1 October 2003 consequent upon Poland's preparations for entry into the European Union. Prior to this time, rural populace in both Russia and Poland conducted large-scale formal and informal trade across their common boundaries freely. The resultant situation includes long and debilitating queues and the hampering of trade between the neighbours. See further RIAN, Russia, Poland Introduce Visa Regime, Pravda, 1 October 2003 (http://newsfromrussia.com/world/2003/10/01/ 50268.html).

51 Consider the reports of Turkish Militia actions against Kurdish populations along the Iraq-Turkey border Owen Bowcott, Buffer Zone Proposal, The Guardian (London), 11 February 1997, 11.

52 Exchange of fire between Indian and Bangladeshi border guards at a frontier outpost is a feature of the tense border relations between the two countries since the partition of the subcontinent into India and Pakistan in 1847. The ownership of several villages on both sides of the border is disputed and claimed by both countries. BBC News, India-Bangladesh Border Battle, Wednesday, 18 April 2001 (http://news.bbc.co.uk/2/hi/south_ asia/1283068.stm). Note also long-standing Isreali-Lebanon problems. See BBC News, Fighting Erupts on Lebanon Border, Sunday, 26 November 2000 (http://news.bbc.co.uk/2/hi/middle_east/1041319.stm). 


\section{IV.D. Innovative gestures of peace and harmony}

There are other innovative, territorial creations and analogies of symbolic, if not practical, value that Cameroon and Nigeria could resort to in settling their border differences while giving effect to the ICJ judgment. It is notable that after the Court's ruling, the leadership of both countries signified at least a political interest to infuse the international relations with "confidence building measures". The Presidents of both States after the ICJ ruling stated that it was necessary for their States to embark on "developing projects to promote joint economic ventures and cross-border cooperation". 53 Projects which may be considered by the parties include the joint development of resorts, parks and "international villages" along part(s) of their common boundary. Other viable options include the unitization of the straddling oil fields, joint Eco-tourism, territorial trade-off and land-for-oil trade-off, among others.

One such laudatory example which may be adopted with respect to one or more of the straddling communities is the International Peace Garden, created to commemorate over 150 years of peace between the United States and Canada. This feature straddles the world's longest unguarded international boundary and is situated in the scenic Turtle Mountains between North Dakota and Manitoba, and half way between the Atlantic and Pacific coasts. Situated at the mouth of this feature are the flags of both nations, and on a boundary marker is inscribed "To God in his glory, we two nations dedicate this garden and pledge ourselves that as long as man shall live, we will not take up arms against one another". The most prominent structure-the Peace Tower, with its four pillars-stands over 100 feet tall astride the exact geographical co-ordinates separating the international boundary. ${ }^{54}$

There is, therefore, much precedent for innovative co-operation among the two States Parties to the ongoing negotiations. Similar basis for co-operation upon which such developments could be initially built includes projects under the Lake Chad Basin Commission (LCBC). It is noted that the current Mixed Commission discussed the possibility of reactivating the work of the LCBC and agreed to convene at their earliest convenience an extraordinary summit of all the Member States. The World Bank very recently approved a grant for the work of the LCBC. ${ }^{55}$ Note may be taken of certain confidence-building efforts that the parties have in view, such as the upgrading of the Mamfe-Abakaliki road

53 See para.7 of the Joint Communique by the Delegations of Cameroon and Nigeria issued after the Meeting Between the United Nations Secretary-General and President Biya and President Obasanjo on the 10 October 2002 Ruling of the International Court of Justice, Geneva, 15 November 2002.

54 Inspiration for the idea came through the private efforts of a certain academic (Dr Henry Moore of Islington, Ontario) and culminated in the gathering of 50,000 people on 14 July 1932 to dedicate the territory to peace. Spreading over 2,339 acres, the territory displays a spectacular mosaic of flowers, trees, fountains and paths. Visitors can stroll through the formal gardens, camp under aspen and oaks, or even get married in the Peace Chapel. Concerts, arts festivals and renowned youth summer camps in music and athletics are also held in there. Over 250,000 people visit the Garden during the summer months alone to help renew the pledge of friendship between Canada and the United States. See Sheldon Green, A Garden for Peace, 21 North Dakota Horizons, No.3 (1991); see also Sonja Rossum, International Peace Garden Centre for Great Plains Studies, University of Nebraska, Lincoln (www.unl.edu/plains/publications/egpentries.html\#peace).

55 See Communiqué Adopted at the Second Meeting of the Cameroon-Nigeria Mixed Commission Established Pursuant to the Joint Geneva Communiqué of 15 November 2002 (Abuja, 4-5 February 2003). 
to Kumba and Mutengene on the Cameroonian side to the development of early warning systems to alert the relevant local authorities and affected populations about potential natural or other disasters. ${ }^{56}$ It may be suggested that if the two States exhibit high levels of political resolve, significant financial help could be expected for innovative territorial arrangements, such as parks and conservation gardens, from the international donor community, which has already responded in various ways to the positive attitude of the parties after the ICJ judgment. ${ }^{57}$

In the interim, both States must refrain from adopting policies which serve to freeze the natural development and spread of the citizens of the other State. This may involve restrictive use of building permits, enforced by selective house demolitions, arrests, fines and daily

harassment, all designed to confine such a population to small enclaves. ${ }^{58}$

It is incumbent upon the parties to do all that are within their power to avoid the problem of Statelessness as a consequence of the demarcation of their entire boundary. Although the possession of a nationality is a condition of enjoying certain benefits and facilities (a passport, diplomatic protection, the benefit of certain treatment under international agreements, etc.), international law does not require that every person shall have a nationality. This could only be brought about by special agreement, for it is an inevitable corollary of leaving the determination of nationality to the laws of individual States that some persons may find themselves nationals of no State under those laws. Effort must, therefore, be directed towards avoidance of such results as a consequence of the handling of straddling villages and communities in this case. ${ }^{59}$

\section{The argument for avoidance of insensitive demarcation}

It is particularly crucial that the negotiations regarding straddling villages are as comprehensive and as honest as possible, given the fact that both family and economic life of the inhabitants of these villages may become disrupted as a result of insensitive "line in the sand" approach to the demarcation tasks. At least on the Nigerian part, there is the political understanding that there is the need to conduct a considerably robust debate about the issue of straddling villages and the special problems that will face the local people as a result of

56 The EU, for instance, has granted 400,000 for the needs of the Mixed Commission and aims to provide an additional grant of four million Euros. See Communiqué Adopted at the Fourth Meeting of the CameroonNigeria Mixed Commission Established Pursuant to the Joint Geneva Communique of 15 November 2002 (Abuja, 10-12 June 2003).

57 See paras 8 and 11 of the Communiqué Adopted at the Third Meeting of the Cameroon-Nigeria Mixed Commission Established Pursuant to the Joint Geneva Communiqué of 15 November 2002 (Yaoundé, 2-3 April 2003).

58 Such an unfortunate regime has been described as the 'matrix of control' in relation to Palestinian villages bordering Israel (i.e. within the context of Isreali dominance). See Jeff Halper, The Key to Peace: Dismantling the Matrix of Control, 28 June 2002 (www.jerusalemites.org/facts_documents/peace/28.htm); see also Habitat International Coalition, Housing and Land Rights Committee Statement Before the Committee on Economic, Social and Cultural Rights, 24th Session, Geneva, 13 November 2000, General Item: Follow-up Procedure (Israel) (www.cesr.org/programs/palestine/hicgeneva.pdf).

59 See British Digest of International Law, Pt VI (London, Stevens and Sons, 1965), 9. 
the Court's judgment. The Nigerian Vice-President, at the beginning of the deliberations during the second meeting of the Mixed Commission, noted that "I expect that your meeting will address the practical problems associated with the ICJ Judgment in respect of the various sectors of the boundary which include the following: the fate of the communities found on the other side of the boundary as a result of the ICJ decision". ${ }^{60}$ Earlier on, the leader of the Nigerian Delegation to the Mixed Commission, Bola Ajibola, underscored the policy of the Nigerian government as follows:

In dealing with the matter(s) at hand, what is of utmost concern to the Nigerian Government and its peoples is not about the resources found in the common border, which are the fish and the oil. We are more concerned with the interest of Nigerian nationals who have, since time immemorial and historically, lived in the area. $^{61}$

With the commendable withdrawal of the Nigerian troops from Lake Chad completed in December 2003, the background of genuine co-operation has been created, making it easier for both parties to make necessary compromises. Nigeria, for instance, may make it known that villages that obviously belong to either side ought not to be divided up without sensitivity to the fate of the local populace.

It, however, cannot be taken for granted that promises made by the States at the present time that they will continue to safeguard the human and economic interests of foreigners placed within their territory as a result of the demarcation process will be faithfully followed in perpetuity. History has shown that when States promise to safeguard the interests of each other's nationals in similar situations, these undertakings are hardly ever honoured in practice. A good example is the ongoing regime of minority protection based on mutually beneficial and reciprocal basis between Greece and Turkey under the Treaty of Laussane. Despite the reality of both States being parties to the European Convention on Human Rights, as well as the major international human rights instruments, today it is recognized that both the Muslim minorities in Western Thrace as well as the Greek minority in Istanbul are "hostages" of the Greek-Turkish relations. As a matter of fact, both States have made "minority rights an apple of discord in inter-State relations and often a pawn in the chessboard of their geopolitical antagonisms". ${ }^{62}$ The principle of reciprocity upon which the Treaty of Lausanne is based has provided Greece and Turkey with the opportunity to interfere in each other's internal affairs. Rather than having the positive effect intended, the Laussane Treaty has resulted in the deterioration of the minorities' status and well-being.

60 See Keynote Address by His Excellency Atiku Abubakar GCON Vice-President Federal Republic of Nigeria on the Occasion of the Second Meeting of the Nigeria-Cameroon Mixed Commission held in Abuja, 4-5 February 2003.

61 See the opening speech of Prince Bola at the first meeting of the Mixed Commission hosted at Yaoundé on 1 December 2002.

62 Anagnostou Dia, Collective Rights and State Security in the New Europe: The Lausanne Treaty in Western Thrace and the Debate about Minority Protection, in: Konstantine Arvanitopoulos (ed.), Security Dilemmas in Eurasia (Athens, Nireefs Press, 1998), 129. 
Over 100 years after this regime of reciprocal protection of minorities was created, scholars of Greek-Turkish relations note severe failings which have costly implications on human lives. ${ }^{63}$ The fate of the Greek minority in Istanbul may be described as even more pathetic. Their numbers have dramatically reduced from 279,788 people in 1924 according to Turkish census figures to a meagre 2500 people today. ${ }^{64}$ The reduction of guaranteed rights into treaties or agreements may not offer foolproof protection for the affected populations. As one writer puts it:

For example, in the case of the Muslim minority in Western Thrace, despite the legal protection afforded to the members of the minority group, which derives from the terms of the Treaty of Lausanne and contemporary human rights law, the Muslim minority on its average still counts in the lowest socio-economic levels in the area. ${ }^{65}$

Perhaps no other group understands the definitive significance of a demarcation exercise than the affected population themselves, considering that, in most cases (as in the CameroonNigeria experience), the demarcators and negotiators are usually from the educated urban elite population. The affected rural population would usually have a unique viewpoint of the impending problems that is difficult to perceive by observers. Yemeni and Saudi border tribes comprising most of the entire population straddling the 1934 Yemen and Saudi Arabia common-border area upon the publication of the Treaty of Jeddah immediately declared their opposition to its content because they believed that the new boundary line would cede large parts of their territory to the other party. A tribal conference, held in the aftermath of the signing of the Treaty of Jeddah and led by northern Yemeni ethnic groups of Wa'ilah and Dahm-alhamra, issued a declaration rejecting the Treaty of Jeddah's innovations and consequences as "unjust". The groups vowed to thwart by force the work of the projected demarcation commission and Survey Company. ${ }^{66}$

On the whole, it is possible to argue that the best solution in such cases is for each State to retain sovereignty over its own nationals where their ethnic origin is clear and where they can

63 One such scholar notes as follows: "The Muslim minority in Western Thrace has often found itself in a less favourable position in many occasions in the past. In particular, the Muslim minority has suffered unequal treatment and severe administrative difficulties, during the 1980 s due to political circumstances, still some serious problems persist. Under such circumstances, it is obvious that the members of any minority group would find themselves in a disadvantaged and weak position in relation to the majority of the society .... As a consequence, the members of an ethnic group cannot effectively participate in the social and cultural life of the society, which they are living and take advantage of the wider social benefits enjoyed by the rest of the Greek citizens." See Konstantinos Tsitselikis, The International and European Status for the Protection of the Linguistic Minority Rights in the Greek Legal Order (Athens, Ant. N. Sakoulas, 1996), 297; see also Iris Boussiakou, The Legal Status of the Muslim Minority in Western Thrace: Efficacy of the Present Regime in the Light of Current International Human Rights Law, PhD thesis submitted at the University of Kent (2003), 61-2 and generally.

64 See Alexandris and Veremis Thanasis, The Greek-Turkish Relations 1923-1987 (Athens, Gnosi, 1988 ), 39.

65 Boussiakou, above n.63.

66 Askar Halwan Al-Enazy, International Boundary Treaty (Treaty of Jeddah) Concluded between the Kingdom of Saudi Arabia and the Yemeni Republic on June 12, 2000. The Current Development, 96 AJIL (2002), 169; Sheik Bin Shaji' Threatens to Thwart any Demarcation Attempts, Yemen Times, 26 June-2 July 2000 (www.yementimes.com/00/iss26/); see also Dahm Tribe Rejects the Jeddah Border Treaty and Threatens Demarcation Companies, Yemen Times, 30 April-6 May 2001 (www.yementimes.com/00/iss18/). 
still be included in its territory by mere adjustments to contiguous boundaries. The UN Cartographic Office, in handling the production of the preliminary imagery map that is used for the current demarcation exercise, understandably relies on the ICJ interpretation of the boundary. Where the ICJ interpretation is not clear or it leads to absurdities, it is expected that the cartographers and the demarcation team will have to rely on other authoritative sources such as the legal instrument defining the boundary. The problem, however, is that these legal instruments did not envisage or take into account the existence of straddling villages at the time at which they were made. In fact, the straddling villages that exist today were not in existence at the time at which the treaties were drawn up. Thus, when the Court quite disturbingly threw up its arms in paragraph 124 and decided that the boundary must pass "close to the village of Kotcha", but leave the cultivated land of the Nigerian village to Cameroon, the provisions of the Thompson-Marchard Declaration of 1913 which governs that sector of the boundary can bring no further clarity. Paragraph 27 of the Declaration simply reads:

Thence from the top of Mount Mulikia to the source of the Tsikakari, leaving Kotcha to Britain and Dumo to France and following a line marked by four provisional landmarks erected in September 1920 by Messrs. Vereker and Pitions.

It is clear that this provision will not on its own solve the problem of the people of Kotcha that have inadvertently spread into a neighbouring State in a region of Africa where efficient boundary management has not been the hallmark of local or national governance.

Further more, it is significant to note that the surveying techniques that were available to the colonial powers as at the time at which the relevant colonial treaties were drawn up are far from being as sophisticated as the ones available today. Indeed, the inherent ambiguities in the Thompson-Marchand Declaration alone were a source of worry to the Court itself and there were questions as to which branch of named rivers to follow, as well as irreconcilable differences in the nomenclature of geography. As alleged by Nigeria in its written submissions to the ICJ, it was not unknown for colonial surveyors "to round things up" in order to save themselves from further bother or embarrassment at doing a shoddy job and coming up with unsupportable maps. Although Nigeria and Cameroon gained political independence in 1960, as far back as 1890, Lord Salisbury admitted:

We have been engaged ... in drawing lines upon maps where no white man's feet ever trod; we have been giving away mountains and rivers and lakes to each other, but we have only been hindered by the small impediment that we never knew exactly where those mountains and rivers and lakes were. ${ }^{67}$

Thus, the only reasonable thing to do in the light of our discussions above is to adopt, as much as possible, the view that the demarcation must proceed along the lines determined by the Court but that where it would occasion manifest injustices or absurdities, such as

67 See Memorial of Libya in the Territorial Dispute (Libyan Arab Jamahiriya/Chad), Vol.1, 25, para.3.01, quoted from The Times, 7 August 1890. 
splitting a school compound into two halves or separating families from their means of subsistence, the legal boundary would cease to be useful and will only be indicative of the direction in which the demarcation must follow for as long as the manifest absurdity is avoided.

If the option of splitting of straddling villages is eventually adopted, it is necessary to point out that the right of inhabitants of straddling villages to leave the country should be guaranteed in a watertight agreement. Human rights non-governmental organizations have for long noted discrimination in the treatment of groups wishing to exercise freedom of movement within straddling communities. Often, whole populations would be equated with the activities of one individual, a particular regime or incidents which occurred during previous political disputes between the neighbouring States. At other times, when the communities have been split up into two States, the right of freedom of movement would only be extended to those regarded as coming from the favoured side. ${ }^{68}$

The close involvement of the United Nations in the demarcation process and with the general implementation of the ICJ judgment in this particular process is unique. The UN Secretary-General quickly brought the presidents of both States into direct negotiations, and all implementation bodies are tripartite in nature and discussions are conducted under the direct leadership of the United Nations. ${ }^{69}$ The UN cartographic experts handle the acquisition of satellite data and would draw up the final demarcation maps. Added to this is the fact that the ICJ is but one of the principal organs of the United Nations. Taking these facts into consideration, it would not be difficult to trace both the successes and possible failures of the entire process to the United Nations itself. This may include responsibility for shortcomings and even violations of human and people's rights. The responsibility of the United Nations if there are identifiable lapses and violations in these circumstances may arguably be derived from the authority of the Reparations case. ${ }^{70}$ The Court unanimously concluded in that case that the organization has the capacity to bring an international claim against a State (whether a Member or non-Member) for damage resulting from a breach by that State of its obligations towards the organization. Under most developed legal systems, it is a recognized principle that benefits and burden go together. It is, therefore, possible to argue that since the United Nations is in a position to bring actions against States on behalf of its agents for loss and damage suffered in UN service, the organization ought to conduct all its international engagements so as prevent all forms of human-rights abuses arising from its actions in

68 International Service for Human Rights (ISHR), Fight against Discrimination and Protection of Vulnerable Groups (www.ishr.ch/About\%20UN/Reports\%20and\%20Analysis/Sub\%2052\%20\%20Discrimination.htm).

69 The importance of the personal involvement of the Secretary-General of the UN in the post-adjudication processes cannot be lost to but the most undiscerning observer. There is undeniably a sense of the maturing of Africa in the images of UN Secretary-General Kofi Anan (himself a son of Africa) hosting the Presidents of two neighbouring African States in high-level tripartiate diplomacy in furtherance of the implementation of a successfully completed adversarial proceeding before the principal judicial organ of the world. The fact that this occurred at a time at which many other African States are experiencing volatile internal and external situations has indeed set the tone for a new era of diplomacy in Africa.

70 Reparation for Injuries Suffered in the Service of The United Nations (Advisory Opinion of 11 April 1949), ICJ Reports (1949), 174. 
those States. Note should also be taken of the attempts to indicate the responsibility of the United Nations for the consequences of regimes that it brings into existence. With regard to the debate on compensation for sanctions damage, the European Court of Justice (ECJ) recently hinted at the responsibility of the United Nations for Security Council sanctions. This, of course, is in opposition to the UN policy to always seek direct victims to present their claims against States. ${ }^{71}$

Woodrow Wilson, former US President, during the inter-war years, warned against the "barter[ing] about" of people "from sovereignty to sovereignty as if they were mere chattels and pawns in a game". ${ }^{72}$ This caveat more than ever holds true today. The splitting of villages in accordance with the judgment will, for instance, imperil the interests of the thousands of affected people in several respects. First, there is the possibility (despite any present assurances) that such people would be perceived as security risks. National interests may be advanced as a reason to subject them to compulsory relocation by the territorial State. Secondly, the population could become subject to burdensome restrictions applicable only to aliens, such as the requirement for residence permits, visa requirements, etc. Thirdly, their property rights, especially in respect of immovable property, could be abridged or extinguished. An example of this is the Cameroonian law that targets foreigners in the boundary areas and prevents them from legally owning landed property. ${ }^{73}$ Particularly because issues of territorial sovereignty may be at stake, it is foreseeable that the freedom of movement or rights of passage of the inhabitants of straddling villages would be a sensitive issue in the international relations of both States. There may be perceived security threats by either side emanating from these settlements in the future. In such situations, it would be most difficult to prove that restrictions may or may not be reasonable given (among other reasons) the history of the dispute and any surrounding tense political or security situation.

71 See Sub-Commission on the Promotion and Protection of Human Rights, The Adverse Consequences of Economic Sanctions on the Enjoyment of Human Rights, UN doc. E/CN.4/Sub.2/2000/33, para.6. Note Recommendation B.2 with respect to non-governmental organizations and victims of sanctions: "Victims of sanctions having adverse consequences should bring their complaints to relevant national, international and regional bodies." For wider discussions on the issue of liability of the UN in sanctions regimes, see Reinisch, August, Developing Human Rights and Humanitarian Law Accountability of the Security Council for the Imposition of Economic Sanctions Notes and Comments, 95 AJIL (2001), 851-70.

72 Baker and Dodd (eds), War and Peace: Presidential Messages, Addresses, and Public Papers (1917-1924), Vol.I (Harper and Brothers, 1927), 182. See also Seokwoo Lee and Dakas C.J. Dakas, The Right to SelfDetermination in the Context of Territorial Disputes: The Kurile Islands in Perspective in Special Issue, Human Rights Law Review, a publication of the University of Nottingham Human Rights Law Centre (2000), 18, 22-23.

73 Cf. Dakas C.J. Dakas, Bakassi, Nursing the Wounds of our Colonial Past (I), This Day Lagos, 30 October 2005 (www.thisdayonline.com/archive/2002/10/22/20021022law07.html and www.africast.com/article.php?news $\mathrm{ID}=43190$ \&strRegion=Central). The concept of affected population is one which is quite vague and has both a wide and a narrow sense. In its narrow sense, it may be said to refer to the population in both countries along the judgment line indicated in the ICJ judgment of 10 October 2002, i.e. from the tripoint in Lake Chad in the north, through the land to the Bakassi Peninsula and until it joins the Atlantic Ocean in the south. In its wide sense, affected population would refer to the entire "constituent population" that lies on both sides of the delimited boundary and, in this way, includes the entire population of Cameroon and Nigeria. 
In the light of the above arguments and in the context of contemporary African human-rights realities, it may prove damning for the citizens of either State to find themselves as a minority population in another country, the languages of which they cannot speak and to the government of which they are not accustomed to offering loyalty. Where this can be avoided by intelligent demarcation, it ought to be done. Therefore, the straddling villages which consist primarily of the citizens of one of the parties ought to be left whole to that party.

It is also unlikely, as stated earlier, that the creation of enclaves would be workable. For instance, in the Right of Passage case, even though the Court found that Portugal had, in 1954 , a right of passage in certain parts of India with respect to private persons, civil officials and goods in general, the Court decided that events which had occurred around 21-22 July 1954 had created tension in the surrounding Indian district, and India's refusal of passage was covered by its power of regulation and control of the right of passage of Portugal. ${ }^{74}$ It is, therefore, respectfully submitted that insensitive demarcation of the straddling villages in the context of Nigeria-Cameroon relations in accordance with the ICJ demarcation is little more than a recipe for future chaos and conflict. There is no doubt that the history of the boundary and territorial dispute between Cameroon and Nigeria has been a long and tortuous one. Political grievances may still run deep, especially among the ethnic groups. ${ }^{75}$ In fact, it would be surprising if that is not the case.

Having been given this opportunity to give the final demarcation exercise a human face, both Cameroon and Nigeria need to enter into further negotiations, as envisaged by the Court in its judgment, particularly paragraphs 107 and 123. The precise solutions must be worked out in close consultation with the communities involved in the specified villages. But it is pertinent to discuss here the direction that the parties must not take. To begin with, it is necessary to consider measures to be put in place in those villages to preserve the ethnic and demographic status quo. This is in order that an accurate assessment may be made of the ethnic and socio-cultural demarcation requirements, which takes into account human rights and the natural desire of families and the entire community to remain within the same country. To this end, both parties have to be vigilant and must not be complacent in preventing deliberate and/or clandestine population transfers which are orchestrated for

74 Right of Passage over Indian Territory (Portugal v. India) ICJ Reports (1960) (see also summary at www.icj-cij. org/icjwww/idecisions/isummaries/ipoisummary600412.htm).

75 The parties have in recent times openly acknowledged the deep-rooted nature and extent of their past disagreement. In a letter to the international donor community, both parties acknowledged that "Relations between the two countries have long been strained due to problems along their common border .... Tensions between the two countries degenerated into military confrontation at the end of 1993". See the Cameroon-Nigeria Mixed Commission, Sub-Commission on Demarcation of the Land Boundary Application for Funds to the Donor Community July 2003. A Nigerian writer was of the opinion that "Before the suit was filed by Cameroon, she had long been subjecting Nigerians in the Peninsula to all sort of brutalities ranging from false imprisonment, murder and intimidation. In 1981, the Cameroonian armed forces made an incursion to the Peninsula and murdered a contingent of Nigerian troops from the 13th Amphibious Brigade, Calabar. Nigeria reacted forcefully by moving troops to her boundary with Cameroon, some how Cameroon realized the foolhardiness of her armed forces and profoundly apologized". See further Okoi Obono-Obla, Bakassi: Matters Arising, The Guardian, Lagos, Sunday, 20 October 2002 (http://news.biafranigeriaworld.com/archive/ngguardian/2002/oct/20/ article 18.html). 
political ends. ${ }^{76}$ Mutual allegations have already been levied on this issue in the past and it will amount to unforgivable oversight to completely ignore the possible effects and ramifications of this in resolving issues surrounding straddling villages. The primary consideration is to ascertain whether artificial tampering with the ethnic demography of straddling villages has occurred. Where this is proven, such machinations must invariably be taken into consideration in the decision as to which of the two States will retain the village. The use of plebiscites and referenda is also recommended, to ascertain the true wishes of the affected population.

It also makes sense to propose that even when a straddling village has been left intact in favour of one of the States, that State must enact legislation targeted to protect foreigners and the people in border areas and within the former straddling community from hostility, discrimination and xenophobic policies. It should be borne in mind that public international law protects the interests of the territorial State in cases in which international easements and flexible territorial arrangements have been created in such a way that the rights of the nonterritorial State may become extinguished or merely symbolic.

Apart from the use of localized referenda to decide which State will retain a straddling village, other factors that may be used to determine which State retains ownership and control include availability and types of access routes to the particular village in question. Where access is possible only through one State, that will be an indication as to which State has traditionally been in the closest relationship with the straddling community. (This appears to be the case with Turu, for instance, where the escarpment on the Nigerian side prevents easy access to the new boundary, which divides this straddling village.)

Other strategies and good practices that may be useful include the creation of demilitarized zones (DMZ) around boundary and border villages if fresh tensions arise-a quite unlikely circumstance in the Cameroon-Nigeria process in light of sustained diplomatic and legal actions since the ICJ judgment. ${ }^{77}$ Where the relations between the boundary and border villages are excellent, new border crossing points may be created to ease the transportation of the population. Even where these are not expressly created by the authorities concerned between both States, it may be envisaged that in practice, the concerned communities would simply continue to move across boundaries in accordance with their daily needs, since the boundaries would remain artificial, even though there would be beacons and markers in place. Such crossings were opened on the Albania-Greece border, near the

76 This, of course, is a problem familiar to lawyers and policy makers dealing with situations in which occupying powers move their citizens into occupied territories, in contravention of UN conventions and public international law. Non-governmental organisations have consistently denounced increasingly growing instances concerning the implantation of settlers in the Western Sahara (and it was suggested that a wave of settlers and heavily armed Javanese commandos were diluting the native presence in the Moluccas Islands). At worst, this policy involves ethnic cleansing as a weapon against indigenous peoples, as evidenced in Sudan, Angola, Cambodia and Colombia who are fleeing to neighbouring countries and in parts of South and Central Asia. See International Service for Human Rights (ISHR), above n.68.

77 Examples of the creation of DMZs abound. For instance, between North and South Korea, cities, villages and counties located within $20 \mathrm{~km}$ of designated border areas are included in a DMZ, and are entitled to extensive government support for renovation. Plans to Develop Border Areas South of DMZ, Yonhap, Seoul 16/06/2000 South Korea (FBIS-EAS-2000-0616). 
village of Sopic, to enable inhabitants of 15 mountain villages to cross into Greece and vice versa. $^{78}$

As a last resort and after it is clearly impossible to retain a village as a single unit or if its farms have fallen into the territory of another State, Nigeria and Cameroon could resort to recognizing carefully delineated transhumance/usufruct rights. ${ }^{79}$ Even for those villages which are not exactly straddling but have a significant closeness to the boundary line and with the population having previously exercised communal use of grazing land or other such uses, it would be necessary to avoid grave injustices to the population. This can be achieved through the recognition of usufruct rights in the other country for village residents. Since the citizens of both States are likely to experience such problems, the advantages of reciprocity in facilitating such arrangements should be transparent. In such cases and as a last resort, despite our earlier position that enclaves are not a very popular device in the management of territorial and boundary disputes among African States, recourse to the creation of enclaves should not be totally ruled out, as this may be necessary to contain and manage the homes/workplaces/farms, etc. of villagers of one country who end up on the wrong side of the main boundary.

Hopefully, it would not be too late already to make both States agree on a sensible solution to the straddling villages issue, since, presumably, the Bakassi territory which is regarded as the jewel in the crown has been won and lost. Cameroon as the perceived victor of this territory is arguably morally if not legally obliged to adopt a compromise position on the straddling villages issue, especially since it stands to gain from the negotiations regarding the village of Turu. However, the record of the ongoing negotiations indicates that Cameroon has indeed not been as forthcoming as would be desirable on issues relating to resolution of the conflicts between human rights and demarcation. ${ }^{80}$ There is still the hope that reason will prevail to the extent that both States have the interests of parts of their population at stake. To adopt the laudatory words of Mr Amadou Ali, Leader of the Cameroonian Delegation, in the first meeting of the Mixed Commission hosted at Yaoundé on 1 December 2002, "Cameroon and Nigeria have before them a great opportunity to prove that Africa

78 See New Crossing Point 28/05/1999 ATA, TIRANA, 28/5/99 (FBIS-EEU-1999-0528).

79 The Spanish enclaved village of Llivia in France, just east of Andorra, retains valuable transhumance/usufruct rights on French pastures and forests, and has done since the boundary of the village was formally delimited in the mid-1600s. Note that as a compensation for becoming an enclave, Llivia received in property a large French area to the west of the lake of Bouillouses, meant for cattle and forestry. The building of a French hotel (l'hôtel Bones Hores) on this property led to many civil suits. As a result, the hotel will become Llivian property in 2030. See Eef Berns, The Border Markers of the Netherlands (www.grenspalen.nl/llivia/ llivia-in-english.html).

80 Indeed, Olu Adeniji, Minister of Foreign Affairs of the Federal Republic of Nigeria, urged the Commission to give the implementation of the ICJ's judgment "a human face, with particular regard to the concerns and well-being of border communities". Text of a keynote address given by the Minister quoted in para. 3 of the Communiqué Adopted at the Eighth Meeting of the Cameroon-Nigeria Mixed Commission Established Pursuant to the Joint Geneva Communiqué of 15 November 2002 (10-11 February 2004); above n.4. Cf. the Cameroonian position regarding Protocol for the protection of the rights of the affected population, above n.26. 
is capable of averting, managing and resolving their conflicts amicably". 81 The devil is, however, in the detail of timing. Once demarcation is completed, it may be too late to begin the process of bargaining to keep essential fields and farms within the legal reach of those who need them in light of the principles of territorial sovereignty and jurisdiction.

It may be argued that while the Court preaches the importance of negotiations with respect to certain problematic areas in dispute, it had not itself laid good examples in this direction because of its strictly artificial approach to the delimitation tasks. It is possible to criticize the Court's decision on the land boundary, as giving little or no regard to factual and sociological realities, ethnic divisions and ancient usages along the boundary lines. It is also possible to argue that despite the strict terms of reference of the ICJ implementation bodies involved in this matter, only the parties' imagination may restrict them from doing all that is necessary to achieve a fairer determination of the shortcomings in the Court's judgment. Public international law as well as the jurisprudence of the Court recognize that States are in apposition to adopt any equitable solutions that they may agree to in such circumstances.

If, however, against the previous practice of African States on this issue, the option of splitting straddling settlement is adopted, in all the areas involved, the issues that must be ironed out between the parties include the following: the prevention of forced population transfers and the guarantees of the right of members of the affected population to move freely within the country as well as to leave it, the guarantee of their rights to ownership of property on equal terms with everyone in the territorial State and their right to security of persons and freedom from reprisals and political persecution. These issues must be reduced to a clear and concise international treaty that would be designed to apply to all the citizens of both countries that reside in the carefully identified border areas, particularly the straddling communities and the Bakassi Peninsula. It is also desirable that before the demarcation exercise is brought to an end and definitely before the last troops are pulled out by both sides in all areas, a mutual check is made that the legal and treaty obligations entered into by the parties after the judgment and as a result of negotiations have been enacted into local legislation by both parties. The final decision as to whether these conditions have been fulfilled may be left to the Secretary-General of the United Nations.

In the final analysis, the Court's judgment in this case is not infallible. It is ridden with riddles and equations, which the parties are expected to resolve bona fide between themselves. It is probably telling that the operative parts of the Court's final judgment in this case, as indeed in most of the cases it dispenses, is formulated in a way that "the Court finds" or

81 See the opening speech of the leader of the Cameroonian Delegation, first meeting of the Mixed Commission hosted at Yaoundé on 1 December 2002. The problem may, however, lie in the perception as explained by Tim Daniel, Head of Public International Law, Kendall Freeman Law Practice that the recent judgment of the ICJ was substantially in favour of Nigeria in terms of territory gained in the land boundary. The judgment was said to have awarded Nigeria about 170,000 square kilometres and Cameroon gained about 4,000. See Tim Daniel, The A-Z of International Boundary Disputes, paper delivered at International Boundary Disputes in Oil and Gas: Practical Strategies You Can Use to Predict, Manage, and Successfully Resolve Cross-Border and CrossContract Disputes Involving Contested Energy Reserves, at Houston, Texas, 22 October 2003. (A report is available at http://www.public-international-law.com/consultancy_service.cfm?id=3.) 
"the Court decides". The Court never resolves or settles. Resolution, therefore, belongs to the parties. It is hoped that the above exposition may prove useful to the technocrats and decision makers that are involved in resolving many of the issues which are the subject of the ICJ ruling. ${ }^{82}$ It is also hoped that the parties will continue to sustain the constructive spirit which has prevailed so far in the various fora specifically set up to give effect to the Court's judgment.

\section{Conclusion}

In a perfect world, the judgments of international courts and tribunals would immediately be given full effect and complied with by States at all times. We are, however, far from that perfect world if the record of compliance with ICJ decisions is anything to go by. ${ }^{83}$ Although it is good policy to ensure that the finality of judgment is respected, this can only be true of judgments that are clear in all respects and not judgments which leave very important issues and points involving human and generational rights to quarrelsome States to negotiate without stating how this is to be facilitated or achieved (straddling villages), or which leaves important economic rights out of its consideration (fishing rights), or which grants entire swathes of one State's population to another without respect for effectivité, national pride and ancestral rights (Bakassi dispute).

82 There is no doubt that the parties have much to gain and every thing to lose if the present negotiations fail because in spite of their long-standing dispute over their common boundary, the ties between both States run very deep and cut across all strata of their societies. It was insinuated in some quarters of the Nigerian press that President Shehu Shagari backed down from use of force in the response of Nigeria to initial Cameroonian aggression in the Bakassi peninsula during his tenure in the early 1980s because he did not want to confront the then President Ahmadu Ahidjo, who is a Fulani, like him. See ICJ's unjust judgment on Bakassi in This Day Lagos, 30 October 2002 (www.africast.com/article.php?newsID=43191\&strRegion=Central). It is also a fact that the present Minister of Justice and Keeper of the Seals of the Republic of Cameroon, Mr Amadou Ali, has Nigerian antecedents and most of his living relatives are now confirmed to be Nigerian as a direct result of the Judgment. The current Cameroonian Prime Minister, Ephraim Inoni, has close relatives in Nigeria. The Nigerian Vice-President, Atiku Abubakar, also related his closeness to the boundary issue by virtue of the proximity of his own village to the international border.

83 In the Corfu Channel case, for example, Albania, for more than four decades, refused to pay Court-ordered reparations to Great Britain for damage done to British warships by Albanian mines in international straits. It was in fact not until 8 May 1992 that a Memorandum of Understanding was signed between both governments involved to settle the outstanding issues (see ICJ Yearbook (1996), Appendix, 257-8). In the Anglo-Iranian Oil Company case, Iran disregarded the Court's order to refrain from nationalizing a British corporation, pending a final judgment of the Court or agreement between the parties. In the Fisheries Jurisdiction case, Iceland refused to obey an order to enforce a 50-mile fishing zone until the Court ruled on the suits instituted by the UK and West Germany. In the United States Diplomatic and Consular Staff in Tehran case, the Court rendered a unanimous interim order granting provisional measures in favour of the USA. The US Embassy in Tehran had dramatically being forcefully occupied by Iranian "revolutionaries" and at least 50 diplomatic and consular staff were held hostage. Yet, Iran failed to comply with the Court's order and even refused to argue the case before the Court. France similarly largely refused to comply with the Court's decision in the Nuclear Test cases. See M.W. Janis, The International Court, in: M.W. Janis (ed.), International Courts for the Twenty-First Century (The Hague, Kluwer Academic Publishers, 1992), 22-5. See also the Treatment of the Effectiveness of Judgments of the World Court in Gbenga Oduntan, The Law and Practice of the International Court of Justice (1945-1996): A Critique of the Advisory and Contentious Jurisdictions (Nigeria, Fourth Dimension Publishers, 1999), 97-102. 
It is notable that both parties have on various occasions committed themselves to confidence-building measures and strategies. It may be argued that perhaps one of the best ways to display compliance with this noble objective is to vary the demarcation of straddling villages during the current phase of the demarcation exercise in certain straddling settlements if, by so doing, farms and other features that are vital to the sustenance of straddling communities will be saved. This is more so if a teleological interpretation is given to the pertinent colonial treaties upon which the ICJ based its judgment. It is clear that the treaties were meant to reflect effective territorial transfers of whole villages and settlements between Britain and France and to divide the then existing settlements. It is also clear that both erstwhile colonial powers were not completely impervious towards the imperative of safeguarding the interests of the peoples found along the line of territories that they mutually exchanged. ${ }^{84}$ Thus, where communities have now grown into straddle boundaries in a natural way, any fresh demarcation must take this development into account so as to save those communities that are threatened by a strict compliance with treaty rules as confirmed by the ICJ Judgment. It is argued that this is what the colonial parties themselves would have done.

It may be noted that demarcation of international boundaries in accordance with the ICJ decision is an exercise within the scope of public international law as much as it is a scientific exercise. In that case, it must be said that the force of the equitable content of international law ought to be brought to bear on the exercise when it is reasonable to do so. The methods by which the straddling communities along the Cameroon-Nigeria border are to be demarcated are certainly ones to which it is reasonable to apply negotiated equitable considerations. The Court itself has clearly highlighted this fact in several parts of its judgment, in relation to farms and rivers wherein ancient rights of usage have been exercised by the people of one of the two States. The liberty of the demarcators to vary the line is more clearly manifested in those villages identified in this paper since (in all of the known cases) there are no parallel or adjacent communities on the other side of the boundary which will, as a result, fall victim to such deliberate and equitable resolution. The line of delimitation drawn up by the ICJ decision must thus, be varied in the interest of justice, equity and compliance with human and generational rights in those sectors where it would occasion manifest injustices or absurdities, such as splitting a school compound into two halves or separating families from their means of subsistence. In such sectors, the legal boundary would cease to be useful and will only be indicative of the direction in which the demarcation must follow for as long as the manifest absurdity is avoided. Not to adopt this reasoning will be to make not only the ICJ but the UN Cartographic Office and the States Parties all complicit in bringing untold sorrows to the lives of people in the affected boundary communities. That

84 Note, for instance, the attempt to safeguard the fishing rights of various affected Nigerian communities in the Anglo-German Agreement 1913, even while the parties were ostensibly ceding the Nigerian territory of Bakassi to Germany. The Agreement states clearly in Art.26 that "The fishing rights of the native population of the Bakassi Peninsula in the estuary of the Cross River shall remain as heretofore". The natural and logical meaning of these words is that the rights of the fishermen to fish and exploit the living marine resources of the Bakassi Peninsula are preserved in perpetuity. 
is such an appalling vista that every sensible person would say "It cannot be right that these actions should go any further". ${ }^{85}$ If the argument against amendment of the boundary by demarcators is simply that it is not usual to do so or indeed that it has never been done, then it is important to adopt the counsel of Lord Denning in relation to the imperatives of applying international law according to the rules of logic, fairness and equity, even where no precedent exists. He wrote in the celebrated Trendtex case:

Ought we not to act now? Whenever a change is made, some one some time has to make the first move. One country alone may start the process. Others may follow. At first a trickle, then a stream, last a flood ... I would use of international law the words, which Galileo used of the earth: "But it does move." International law does change: and the Courts have applied the changes without the aid of any Act of Parliament. ${ }^{86}$

It is left to the parties to act in the common interest of the affected people and make sure that the communities are as much as possible placed in a position to exist within one single State without the fear of being subject to the difficulties of having their homes, schools, farms and economic interests divided between two sovereign States. The directive considerations for all parties are implicit in the conclusions of the UN Secretary-General's Special Representative for West Africa, Ahmedou Ould-Abdallah, who noted that "The affected populations overwhelmingly want peace ... the affected population are in dire need of development, social services and basic infrastructure" ${ }^{87}$ It is, therefore, imperative that neither the parties nor the United Nations should place impediments in the way of lasting peace and prosperity of all the people affected by the judgment of the ICJ in this celebrated case.

85 Cf. the controversial pronouncements of Lord Denning in his judgment in the case of the Birmingham Six. See McIlkenny v. Chief Constable of the West Midlands [1980] QB, 283, 323D.

86 Trendtex Trading Corp v. Central Bank of Nigeria (Trendtex) [1977] QB, 529; 2 WLR, 356; [1977] 1 All ER, 881; [1977] 1 Lloyd's Rep, 581.

87 UN News Service, Cameroon and Nigeria Discuss Border Dispute During UN Commission Talks (www.globalsecurity.org/military/library/news/2003/10/mil-031030-unnews02.htm). 